\title{
1,1'-Biisoquinolines-Neglected Ligands in the Heterocyclic Diimine Family That Provoke Stereochemical Reflections
}

\author{
Edwin C. Constable $^{1, *(\mathbb{D}}$, Richard M. Hartshorn ${ }^{2}(\mathbb{D})$ and Catherine E. Housecroft $^{1}(\mathbb{D}$ \\ 1 Department of Chemistry, University of Basel, BPR 1096, Mattenstrasse 24a, CH-4058 Basel, Switzerland; \\ catherine.housecroft@unibas.ch \\ 2 School of Physical and Chemical Sciences, University of Canterbury, CT1 1PL Christchurch, New Zealand; \\ richard.hartshorn@canterbury.ac.nz \\ * Correspondence: edwin.constable@unibas.ch; Tel.: +41-61-207-1001
}

check for updates

Citation: ConsTable, E.C.; Hartshorn, R.M.; Housecroft, C.E. 1,1'

Biisoquinolines-Neglected Ligands in the Heterocyclic Diimine Family That Provoke Stereochemical Reflections. Molecules 2021, 26, 1584. https://doi.org/10.3390/molecules 26061584

Academic Editors: Luca Gonsalvi and Maurizio Peruzzini

Received: 2 March 2021

Accepted: 10 March 2021

Published: 13 March 2021

Publisher's Note: MDPI stays neutral with regard to jurisdictional claims in published maps and institutional affiliations.

Copyright: (c) 2021 by the authors. Licensee MDPI, Basel, Switzerland. This article is an open access article distributed under the terms and conditions of the Creative Commons Attribution (CC BY) license (https:/ / creativecommons.org/licenses/by/ $4.0 /)$.

\begin{abstract}
Biisoquinolines are a class of bidentate nitrogen donor ligands in the heterocyclic diimine family. This review briefly discusses their properties and the key synthetic pathways available and then concentrates upon their coordination behaviour. The ligands are of interest as they exhibit the phenomenon of atropisomerism (hindered rotation about the $\mathrm{C} 1-\mathrm{C}^{\prime}$ bond). A notation for depicting the stereochemistry in coordination compounds containing multiple stereogenic centers is developed. The consequences of the chirality within the ligand on the coordination behaviour is discussed in detail.
\end{abstract}

Keywords: ligand; 1,1'-biisoquinoline; bidentate; atropisomerism; chirality; stereochemical nomenclature

\section{Introduction}

The heterocyclic diimines 2,2'-bipyridine (1) and 1,10-phenanthroline (2) and their derivatives are among the commonest chelating nitrogen donor ligands in coordination and organometallic chemistry (Figure 1) [1-10]. The heterocyclic diimine metal-binding domain is widely used as a scaffold in supramolecular chemistry and in interfacial science. Compounds $\mathbf{1}$ and $\mathbf{2}$ are members of a much larger series of bis(heterocycles) incorporating the $\mathrm{N}=\mathrm{C}-\mathrm{C}=\mathrm{N}$ chelating metal-binding motif. This review is concerned with the coordination behavior of one of the less well-known members of this series, $1,1^{\prime}$-biisoquinoline (3) (Figure 1). The 1,1'-biisoquinolines are of especial interest as steric interactions between nitrogen lone pairs, substituents on the nitrogen and between $\mathrm{H} 8$ and $\mathrm{H}^{\prime}$ favour a non-planar geometry in both the free ligands and their chelated metal complexes. The consequences of this are discussed in Section 2.

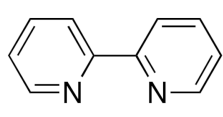

1

2,2'-bipyridine

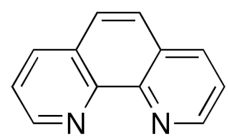

2

1,10-phenanthroline

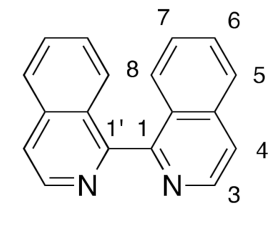

3

$1,1^{\prime}$-biisoquinoline

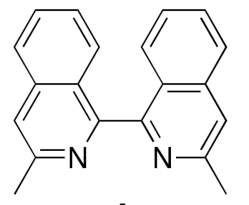

4
Figure 1. The structures of the "parent" heterocyclic diimines 2,2'-bipyridine (1) and 1,10phenanthroline (2) together with that of $1,1^{\prime}$-biisoquinoline (3), the subject of this review. The IUPAC numbering scheme for derivatives of $1,1^{\prime}$-biisoquinoline is indicated and also shown is an example of the abbreviated nomenclature adopted in this review using $3,3^{\prime}-\mathrm{Me}_{2}$ biiq as an example of an abbreviation for 3,3'-dimethyl-1,1'-biisoquinoline (4). 
Derivatives of 3 will generally be named in an abbreviated form utilizing the shortform biiq with the substituents located using the numbering scheme indicated in Figure 1; for example, 3,3'-dimethyl-1,1'-biisoquinoline (4) would be written 3,3'-Me ${ }^{\prime}$ biiq (Figure 1). We note that various abbreviations have been used for 1,1'-biisoquinoline in the literature, including biq and bq, which are also used by other authors for 2,2'-biquinoline.

This review concentrates upon the properties of this interesting class of compounds as ligands and also includes a non-comprehensive overview of their properties and major synthetic routes for their preparation. Condensed and reduced derivatives of biiq are excluded from this review. Much of the interest in 1,1'-biisoquinolines relates to their stereochemical and stereogenic properties, in particular they belong to the class of diaryls which exhibit atropisomerism. In the course of preparing this review, we became aware of a need for a clear notation to describe the stereochemical configuration in coordination compounds containing multiple stereogenic features (centers or axes) and/or chiral ligands. All structural information and figures have been extracted from the Cambridge Structural Database [11] using the Conquest search [12] and Mercury visualization software [13].

\section{Atropisomerism}

\subsection{Atropisomerism}

Before considering the chemistry of the $1,1^{\prime}$-biisoquinolines themselves, it is worth reviewing the concept of atropisomerism.

Atropisomers are stereoisomers which arise as a result of hindered rotation about a single bond, and atropisomerism is a form of axial chirality [14]. In the classical period of organic chemistry, it was assumed that rotation around C-C bonds was, to all intents and purposes, without an energy barrier. Atropisomerism is commonly observed in compounds in which aromatic rings are connected by a single $\mathrm{C}-\mathrm{C}$ bond, with the barrier to rotation arising from interactions between substituents on the aromatic rings (Figure 2a). The first compounds exhibiting atropisomerism to be resolved were $6,6^{\prime}$-dinitro-[1, $1^{\prime}$-biphenyl]2,2'-dicarboxylic acid (Figure 2b) and 4,4',6,6'-tetranitro-[1,1'-biphenyl]-2,2'-dicarboxylic acid [15], although the possibility of such forms of enantiomerism has been predicted earlier by a number of authors [16-18]. It was left to Werner Kuhn to introduce the term atropisomerism (atropisomerie), derived from the Greek $\alpha \tau \rho \circ \pi \circ \varsigma$ (atropos) meaning "without turn", to describe this phenomenon [19].

IUPAC recommends the use of the stereochemical descriptors $P$ and $M$ rather than the more commonly encountered $R_{\mathrm{a}}$ and $S_{\mathrm{a}}$ to denote the stereogenic axis in the Preferred IUPAC Name (PIN) of axially chiral compounds (Rules P-92.1.2.1.2, P-92.1.2.2, P-92.1.2.2.1 and P-93.5. 7.1 and Figure 2b) [20]. Standard Cahn-Ingold-Prelog rules are used to determine the priority of substituents treating the compounds as "extended tetrahedra" with $R_{\mathrm{a}}$ and $S_{a}$ defining a clockwise or anticlockwise sequence (Figure 2c) [21-24]. In particular, those rules are used to identify the order of the two groups at one end ( $a$ and b in Figure 2c), and the higher ranked group (c) of the two at the other end.

The descriptors $P$ and $M$ refer to $p$ lus and minus, relating to a right- or left-handed helicity, respectively. The substituents $\mathrm{a}, \mathrm{b}, \mathrm{c}$ and $\mathrm{d}$ are arranged in pairs looking along the chirality axis. The highest priority substituent in each pair is identified, and the chirality is described as $M$ if the path between these two is anticlockwise, and as $P$ if it is clockwise (Figure 2d). We believe that this is easier to apply than the $R_{\mathrm{a}} / S_{\mathrm{a}}$ approach.

In practical terms, for the isolation of enantiopure forms, the interconversion of atropisomers should exhibit a half-life of at least $1000 \mathrm{~s}$ at $300 \mathrm{~K}$ which corresponds to an energy barrier for rotation of $93 \mathrm{~kJ} \mathrm{~mol}^{-1}[25,26]$. Inorganic chemists are probably most familiar with the phenomenon of atropisomerism in the context of chelating bisphosphane ligands such as BINAP ([1,1'-binaphthalene $]-2,2^{\prime}$-diylbis(diphenylphosphane), 6 , Figure 3a) [27-35]. It is instructive to use ligand 6 to illustrate the consequences of coordination. The free ligand is non-planar as a consequence of the interactions between the 2-PPh 2 and $2^{\prime}-\mathrm{PPh}_{2}$ substituents and also between $\mathrm{H} 8$ and $\mathrm{H}^{\prime}$; this is seen in the solid-state structures of $(2 P)-6\left(P 2_{1}\right)[36,37](2 M)-6\left(P 2_{1}\right)[37,38]$ and rac-6 $(C 2 / c)[37,39]$ which have 
all been reported. In all cases the two aromatic rings of the 1,1'-binaphthalene scaffold are close to orthogonal in the solid state with torsion angles $\mathrm{C} 2-\mathrm{C} 1-\mathrm{C}^{\prime}-\mathrm{C} 2^{\prime}$ in the range 91.536-93.429 ${ }^{\circ}$. Upon coordination, the conformation of the ligand will be influenced not only by the steric interactions within the ligand, but also by the optimization of the metal-donor atom bond lengths and $\angle \mathrm{P}-\mathrm{M}-\mathrm{P}$ bond angles. This is clearly seen in the complex $\left[\mathrm{Pd}\{(2 P)-6\} \mathrm{Cl}_{2}\right]$ (Figure $3 \mathrm{c}$ ), in which the torsion angle $\mathrm{C} 2-\mathrm{C} 1-\mathrm{Cl}^{\prime}-\mathrm{C} 2^{\prime}$ is reduced to $69.9^{\circ}$ enabling optimal Pd-P bond lengths of $2.244 \AA$, a $\angle \mathrm{P}-\mathrm{Pd}-\mathrm{P}$ bite angle of $92.68^{\circ}$ and a concomitant reduction in the $\mathrm{H} 8-\mathrm{H} 8^{\prime}$ distance of $\sim 0.2 \AA$ [40].

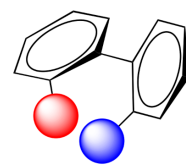

(a)

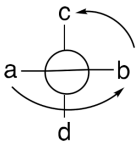

$S_{a}$

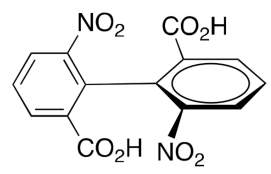

$\left(1 S_{a}\right)-5$
$(1 P)-5$

(b)

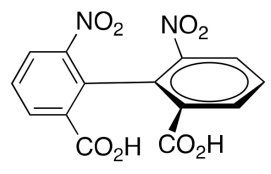

$\left(1 R_{\mathrm{a}}\right)-5$
$(1 M)-5$

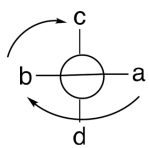

$R_{\mathrm{a}}$

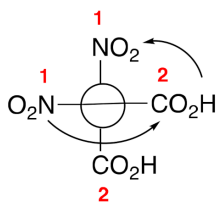

$\left(1 S_{a}\right)-5$

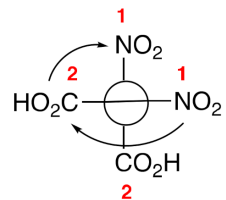

$\left(1 R_{\mathrm{a}}\right)-5$

(c)
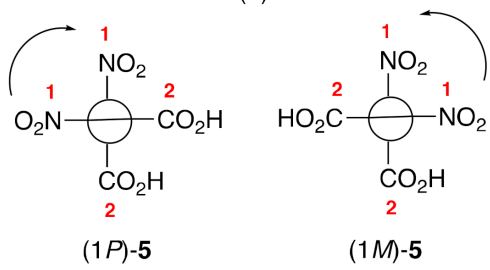

(d)

Figure 2. (a) Steric interactions between the red and blue substituents in biaryls can lead to atropisomerism with the chiral axis being the interannular $\mathrm{C}-\mathrm{C}$ bond; $(\mathbf{b})$ the first atropisomeric compounds to be resolved were the enantiomers of $6,6^{\prime}$-dinitro-[1,1'-biphenyl]-2,2'-dicarboxylic acid; (c) the Cahn-Ingold-Prelog scheme can be extended to the nomenclature of axially chiral compounds using the usual priority rules for an "extended tetrahedron"; (d) but IUPAC recommends the use of $P$ and $M$ assigned using Cahn-Ingold-Prelog priorities as described in the text.

\subsection{Atropisomerism in 1,1'-Biisoquinolines}

1,1'-Biisoquinolines have a chiral axis defined by the $\mathrm{C} 1-\mathrm{C} 1^{\prime}$ bond (Figure 4a). Attempts to resolve the parent compound 3 via the tartrate salt of the protonated ligand were unsuccessful, with mutorotation occurring in aqueous solution within $80 \mathrm{~s}$ in $0.3 \mathrm{M}$ hydrochloric acid [41]. Chiral stationary phases [42] and complexation with chiral palladium complexes [43,44] have been used for the resolution of 3 and 8,8'-dialkyl derivatives [45,46]. Steric interactions are increased with the presence of substituents on the nitrogen atoms, and, in contrast to 3 itself, 1,1'-biisoquinoline $N, N^{\prime}$-dioxide $[47,48]$ and 8, $8^{\prime}-(\mathrm{MeO})_{2}$ biiq $N, N^{\prime}$-dioxide [42] can also be resolved on chiral solid phases. Somewhat unexpectedly, the rate of racemization increases in the sequence $8,8^{\prime}-\mathrm{Me}_{2}$ biiq $<8,8^{\prime}-\mathrm{Et}_{2}$ biiq $<8,8^{\prime}{ }^{i}{ }^{i} \mathrm{Pr}_{2}$ biiq, with activation energies at $303 \mathrm{~K}$ being close to $100 \mathrm{~kJ} \mathrm{~mol}^{-1}[43,46]$. Various chiroptical correlations have been used to show that the (+)-forms of 1,1'-biisoquinolines possess the $(1 M)$ absolute configuration (Figure 4) [42,45,46,49-51]. 


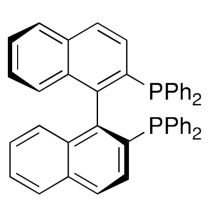

$(2 P)-6$

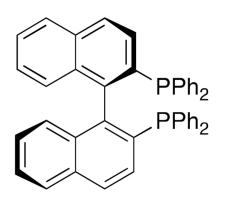

$(2 M)-6$

(a)

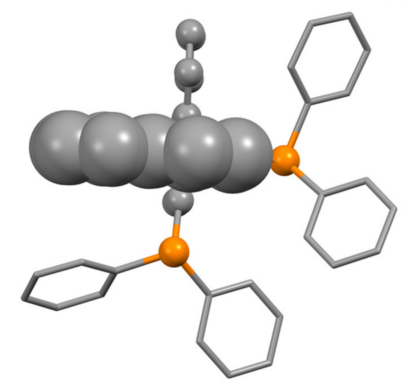

(b)

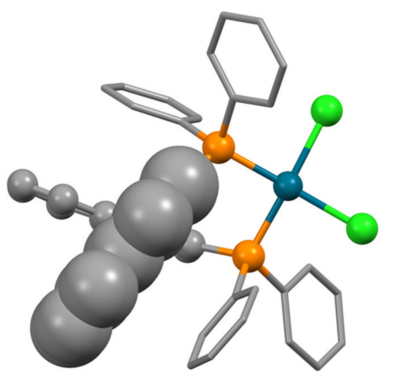

(c)

Figure 3. (a) The two atropisomeric forms of BINAP, $\left[1,1^{\prime}\right.$-binaphthalene $]-2,2^{\prime}$-diylbis(diphenylphosphane), $\mathbf{6}$; (b) in the free ligand the naphthalene rings are near-orthogonal, minimizing mutual interactions between the substituents, hydrogen atoms omitted for clarity, phosphorus shown as balls, the naphthalene closest to the viewer in $70 \%$ space-filling and the remote naphthalene in ball and stick representation; (c) in the complex $\left[\mathrm{Pd}\{(2 P)-6\} \mathrm{Cl}_{2}\right]$ the interannular angle between the naphthalene rings is reduced to $69.9^{\circ}$ allowing Pd-P bond lengths of $2.244 \AA$ and a P-Pd-P bite angle of $92.68^{\circ}$, hydrogen atoms omitted for clarity, phosphorus, palladium and chlorine shown as balls, the naphthalene closest to the viewer in $70 \%$ space-filling and the remote naphthalene in ball and stick representation.

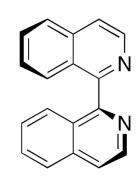

$(1 P)-3$
$\left(1 S_{\mathrm{a}}\right)-3$<smiles>c1ccc2c(-c3nccc4ccccc34)nccc2c1</smiles>

$$
\begin{aligned}
& (1 M)-3 \\
& \left(1 R_{\mathrm{a}}\right)-3
\end{aligned}
$$

(a)<smiles>c1ccc2c(-c3nccc4ccccc34)nccc2c1</smiles>

$(1 P)-3$
syn-(1P)-3

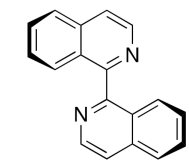

(1P)-3

(b)
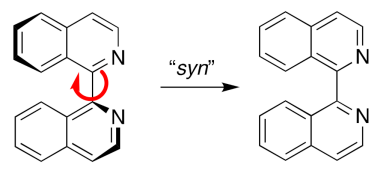
Transition state
$+163 \mathrm{~kJ} \mathrm{~mol}^{-1}$

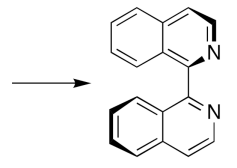

$(1 M)-3$

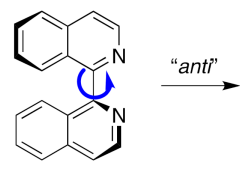

$(1 P)-3$

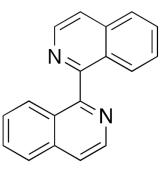

Transition state
$+41.84 \mathrm{~kJ} \mathrm{~mol}^{-1}$

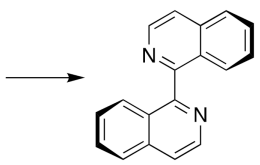

$(1 M)-3$

Figure 4. (a) The two enantiomeric (atropisomeric) forms of 1,1'-biisoquinoline; (b) each enantiomer can adopt a syn or an anti conformation ( syn $\mathrm{N}-\mathrm{C}-\mathrm{C}-\mathrm{N}$ torsion angle $<90^{\circ}$, anti $\mathrm{N}-\mathrm{C}-\mathrm{C}-\mathrm{N}$ torsion angle $>90^{\circ}$ ); (c) racemization can involve a rotation through a syn (the red arrow denotes the direction of rotation of the top quinoline) or an anti (the blue arrow denotes the direction of rotation of the top quinoline) conformation. The latter is favored as the $\mathrm{H} 8$ and $\mathrm{H}^{\prime}$ atoms do not have to pass through each other. 
Computational chemical studies at the MOMM (molecular orbital molecular mechanics) level have been reported for the free ligand biiq and confirm that the anti pathway for racemization is favoured over the syn pathway, with the barrier for syn rotation being estimated at $163 \mathrm{~kJ} \mathrm{~mol}^{-1}$ and that for anti rotation as $41.84 \mathrm{~kJ} \mathrm{~mol}^{-1}$ [52].

Macrocyclic ligands (Figure 5) incorporating 1,1'-biisoquinoline subunits have been of interest in studying the influence of the additional ring constraints on racemization. Compounds 7 and 8 were prepared from the appropriate open-chain bis(1-haloisoquinolines) using an Ullmann reaction and resolved using HPLC on a chiral phase [53]. Compound 7 racemized in boiling EtOH with a $t_{1 / 2}$ of $64 \mathrm{~min}\left(\Delta \mathrm{G}^{\ddagger} 110 \mathrm{~kJ} \mathrm{~mol}^{-1}\right)$ whilst 8 is configurationally stable. The larger ring macrocycle 9 exhibits rather more interesting behaviour and displays a dynamic kinetic resolution on treatment with a chiral acid. Rapid racemization takes place in polar and protic solvents, as well as under acidic conditions [54].<smiles></smiles>

7<smiles>COc1cc(COc2ccc3ccnc(-c4nccc5ccc(OCc6cc(OC)cc(OC)c6)cc45)c3c2)cc(OC)c1</smiles>

8<smiles></smiles>

9

Figure 5. Macrocyclic ligands incorporating 1,1'-biisoquinoline metal-binding domains.

\section{Synthesis of $\mathbf{1}, \mathbf{1}^{\prime}$-Biisoquinolines}

The standard works on the synthesis and properties of quinolines and isoquinolines do not contain significant details of the 1,1'-biisoquinolines [55-58]. Although a range of "exotic" methods of synthesis has been reported [55,59-69], the commonest methods relevant to the bulk preparation of ligands for use in coordination chemistry are the oxidative dimerization of isoquinolines (Scheme 1a) and the coupling of 1-haloisoquinolines (Scheme 1b) [70,71].

(a)<smiles>c1ccc2cnccc2c1</smiles>

(b)<smiles>[AlH2]c1nccc2ccccc12</smiles>
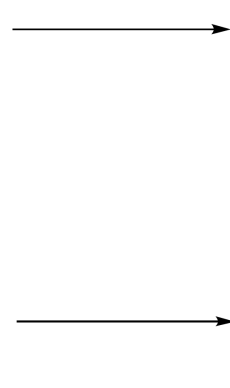<smiles>c1ccc2c(-c3nccc4ccccc34)nccc2c1</smiles><smiles>c1ccc2c(-c3nccc4ccccc34)nccc2c1</smiles>

Scheme 1. The commonest methods for the synthesis of $1,1^{\prime}$-biisoquinolines are (a) the oxidative dimerization of isoquinolines, and (b) the coupling of 1-haloisoquinolines. The various methods are described in detail in the text.

The oxidative dimerization of isoquinoline with LDA/HMPA (LDA $=\mathrm{Li}\left(\mathrm{N}^{i} \operatorname{Pr}_{2}\right)$, HMPA = hexamethylphosphoramide) in diethyl ether is reported to give 3 in $35-55 \%$ yield [72-74], better than the $26.3 \%$ yield obtained from the reaction with sodium naphthalenide $[75,76]$ but not approaching the $87 \%$ obtained from the reaction with $\mathrm{MgCl}(\mathrm{TMP})$ (HTMP = 2,2,6,6-tetramethylpiperidine) [74]. The compound is also obtained from the treatment of isoquinoline with LDA/TMEDA (TMEDA $=N^{1}, N^{1}, N^{2}, N^{2}$-tetramethylethane- 
1,2-diamine) in diethyl ether, although no yield was reported [77]. The dehydrogenation reactions of isoquinoline with transition metals are not especially effective: reaction with $\mathrm{Pd}-\mathrm{C}[78]$ or $\mathrm{Ni}-\mathrm{Al}_{2} \mathrm{O}_{3}$ [79] do not yield 3 and only trace amounts are obtained with Raney nickel [80]. The best yields $(<10 \%)$ are obtained with Rh-C catalysts [80].

The first reported synthesis of $\mathbf{3}$ was from a classical Ullmann reaction of 1-bromoisoquinoline with copper metal at $210-230{ }^{\circ} \mathrm{C}$ [81]. The reaction of 1-bromoisoquinoline with either sodium or magnesium does not yield 3 [79]. The coupling of 1-haloisoquinolines has been achieved with $\mathrm{Zn}-\left[\mathrm{NiBr}_{2}\left(\mathrm{PPh}_{3}\right)_{2}\right]$ [47,82], $\mathrm{Zn}-\left[\mathrm{NiBr}_{2}\left(\mathrm{PPh}_{3}\right)_{2}\right]-\left(\mathrm{Et}_{4} \mathrm{~N}\right) \mathrm{I}[70,83], \mathrm{Zn}-$ $\mathrm{NiCl}_{2}-\mathrm{PPh}_{3}[43-46,84-87]$ or In-[Pd($\left.\left(\mathrm{PPh}_{3}\right)_{4}\right]$ [88] catalysts. Substituted derivatives of biiq which have been prepared using this approach include 3,3'- $\mathrm{Me}_{2}$ biiq [84], 8,8 $-\mathrm{Me}_{2}$ biiq [45,46], 3,3'-Et 2 biiq [84], 8,8 -Et $_{2}$ biiq [45,46], 3,3'-( $\left.{ }^{i} \mathrm{Pr}\right)_{2}$ biiq [84], 8,8 $-\left({ }^{i} \mathrm{Pr}\right)_{2}$ biiq [45,46], 8, $8^{\prime}-\left({ }^{\mathrm{t}} \mathrm{Bu}\right)_{2}-$ biiq [45,46], 3,3'- $\mathrm{Ph}_{2}$ biiq [84], 3,3'-(2-py) $)_{2}$ biiq [84], 6,6'-(MeO) $)_{2}$ biiq [84], 3,3'-( $\left.\mathrm{MeO}_{2} \mathrm{C}\right)_{2}$ biiq [83], $3,3^{\prime}-\left(\mathrm{HO}_{2} \mathrm{C}\right)_{2}$ biiq [83], 4,4'- $\left(\mathrm{C}_{n} \mathrm{H}_{2 n+1} \mathrm{O}\right)_{2}$ biiq $(n=1-11,13,17)[86], 4,4^{\prime}-\left\{{ }^{n} \mathrm{ROC}_{6} \mathrm{H}_{4} \mathrm{O}\left(\mathrm{CH}_{2}\right)_{n} \mathrm{O}\right\}_{2}-$ biiq $\left(R=\mathrm{C}_{6} \mathrm{H}_{13}, \mathrm{C}_{8} \mathrm{H}_{17} ; n=4,6\right)$ [86]. An interesting modern variant on the Ullmann reaction utilizes Au-Pd nanochain networks; 3 is obtained in 77\% yield from 1-chloroisoquinoline on treatment with the Au-Pd nanochain networks and $\mathrm{K}_{2} \mathrm{CO}_{3}$ in aqueous ethanol [89]. Other noteworthy variants are seen in the reaction of 1 -iodoisoquinoline with ${ }^{t} \mathrm{BuLi}$ and $\mathrm{MnCl}_{2}$ followed by aerial oxidation, which gives 3 in 78\% yield [90] or the preparation of 3 from 1-bromoisoquinoline in $30 \%$ yield by reaction with ${ }^{n} \mathrm{Bu}_{6} \mathrm{Sn}_{2}$ and [ $\mathrm{Pd}\left(\mathrm{PPh}_{3}\right)_{4}$ ] [91].

One method likely to be of future application in the synthesis of asymmetric $1,1^{\prime}$ biisoquinolines is presented in Scheme 2: the parent compound 3 is obtained in $46 \%$ yield in gram-scale preparations [92,93].

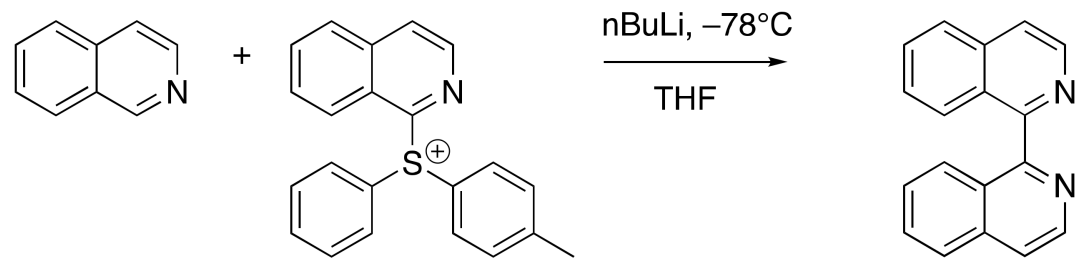

Scheme 2. A new synthetic method with potential for the preparation of asymmetrically substituted $1,1^{\prime}$-biisoquinolines [92,93].

The treatment of isoquinoline $\mathrm{N}$-oxides with $\mathrm{K}\left(\mathrm{O}^{t} \mathrm{Bu}\right.$ ) and AIBN (AIBN = azobisisobutyronitrile) in DMF or THF has been used for the preparation of 3, 3,3'- $\mathrm{Me}_{2}$ biiq, 5,5'- $\mathrm{Cl}_{2}$ biiq and $6,6^{\prime}-\mathrm{Br}_{2}$ biiq in $54-77 \%$ yield [94]. Similarly, the reaction of isoquinoline $N$-oxides with $\mathrm{Li}\left(\mathrm{O}^{t} \mathrm{Bu}\right)$ in chlorobenzene at $120^{\circ} \mathrm{C}$ gives 3 in $50 \%$ yield [95]. Both strategies are potentially of interest for future research in the field.

\subsection{1,1'-Biisoquinoline $N, N^{\prime}$-Dioxides}

$1,1^{\prime}$-Biisoquinoline $N, N^{\prime}$-dioxides (Figure 6 a) are readily prepared from the parent $1,1^{\prime}$ biisoquinolines using classical methods of $\mathrm{N}$-oxidation involving peracetic acid or MCPBA (MCPBA = 3-chloroperbenzoic acid) $[47,48,96]$ and have been resolved using chiral HPLC. The compounds appear to be configurationally stable. Resolved 1,1'-biisoquinoline $N, N^{\prime}-$ dioxides have found some applications as enantioselective organic catalysts $[49,50,97-107]$. The complex $\left(1,1^{\prime}\right.$-biisoquinoline $N, N^{\prime}$-dioxide)dichloridopalladium is an effective catalyst for Suzuki cross-couplings and hydroxyarylation reactions [96].

The conversion of $1,1^{\prime}$-biisoquinoline to its $N, N^{\prime}$-dioxide is expected to increase the steric interactions between the aryl subunits as the oxygen-oxygen interactions are likely to have a greater steric demand than the lone pair-lone pair interaction in the parent compound. Only a single example of a $1,1^{\prime}$-biisoquinoline $N, N^{\prime}$-dioxide has been structurally characterized in a co-crystal of $(1 P)-1,1^{\prime}$-biisoquinoline $N, N^{\prime}$-dioxide and $(1 M)$ [1,1'-binaphthalene]-2,2'-diol [98]. A comparison of the $\mathrm{N} 2-\mathrm{C} 1-\mathrm{C}^{\prime}-\mathrm{N} 2^{\prime}$ torsion angle in $1,1^{\prime}$-biisoquinoline $\left(90.96^{\circ}\right)$ [108] to that in $1,1^{\prime}$-biisoquinoline $N, N^{\prime}$-dioxide $\left(101.64^{\circ}\right)$ [98] 
$\left(101.64^{\circ}\right)$ shows that the oxygen-oxygen interactions dominate and these substituents adopt an anti comformation (Figure 6b).<smiles>[O-][n+]1ccc2ccccc2c1-c1c2ccccc2cc[n+]1[O-]</smiles>

(a)

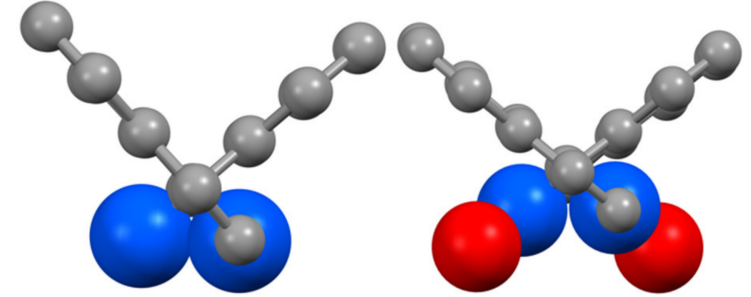

(b)

Figure 6. (a) 1,1'-Biisoquinoline $N, N^{\prime}$-dioxide; (b) in the solid state, the torsion angle $\mathrm{N} 1-\mathrm{C} 1-\mathrm{C} 1^{\prime}-$ $\mathrm{N} 2^{\prime}$ increases from $90.96^{\circ}$ in $(1 P)-1,1^{\prime}$-biisoquinoline [108] to $101.64^{\circ}(1 P)-1,1^{\prime}$-biisoquinoline $N, N^{\prime}$ dioxide [98] showing the importance of oxygen-oxygen interactions. The nitrogen and oxygen atoms are depicted with $70 \%$ space-filling size to emphasize the stereochemistry.

\subsection{Quaternized 1,1'-Biisoquinolinum Salts}

A number of quaternized $1,1^{\prime}$-biisoquinolinium salts have been prepared and characterized using classical alkylating agents (Figure 7) [109-111]. Compounds (10)(I) $)_{2},(\mathbf{1 1})(\mathrm{Br})_{2}$, $(12)(B r)_{2}$ and $(13)(B r)_{2}$ exhibit a blue chemiluminescence in basic solution that is enhanced in the presence of $\mathrm{H}_{2} \mathrm{O}_{2}$. The reaction products are $N, N^{\prime}$-linked isoquinolin- $1(2 \mathrm{H})$-ones arising from cleavage of the $\mathrm{C} 1-\mathrm{C} 1^{\prime}$ bond [111-113]. Several of these compounds have been structurally characterized and these are presented in Section 4.1.<smiles>C[n+]1ccc2ccccc2c1-c1c2ccccc2cc[n+]1C</smiles><smiles>CCCCC[n+]1ccc2ccccc2c1-c1c2ccccc2cc[n+]1C</smiles>

$11 n=2$

12

$$
n=3
$$

13

$$
\mathrm{n}=4
$$

\section{0}

Figure 7. Some 1,1'-biisoquinolinium cations.

\section{Some Relevant Physical and Structural Properties of $1, \mathbf{1}^{\prime}$-Biisoquinolines \\ 4.1. Structural Studies}

A number of $1,1^{\prime}$-biisoquinolines and derivatives has been structurally characterized and relevant data are presented in Tables 1 and 2. Table 1 presents "simple" 1,1'biisoquinolines and Table 2 comprises quaternized and related derivatives. Structurally characterized metal complexes are discussed individually in the relevant sections. In all cases, the individual biisoquinoline ring systems are near-planar and torsion angle N2-C1$\mathrm{C}^{\prime}-\mathrm{N} 2^{\prime}$ is used as a measure of the relative orientation of the rings about the interannular $\mathrm{C}-\mathrm{C}$ bond that defines the chiral axis. It is also worth commenting that no structure of an enantiopure 1,1'-biisoqiuinoline has been reported to date, with all structures being in non-Sohncke space groups and containing both atropisomers. The structure of the $(1 P)$ and (1M)-enantiomers of biiq are presented in Figure 8.

Quaternized 1,1'-biisoquinolines are expected to have higher barriers to racemization (as discussed for 1, $1^{\prime}$-biisoquinoline $N, N^{\prime}$-dioxides in Section 3.1). Nevertheless, all quaternized and protonated 1,1'-biisoquinolines are in non-Sohncke space groups. 
Table 1. Structurally characterized 1,1'-biisoquinolines.

\begin{tabular}{|c|c|c|c|c|}
\hline Compound & Refcode & $\mathrm{N} 2-\mathrm{C} 1-\mathrm{C}^{\prime}-\mathrm{N} 2^{\prime} /^{\circ}$ & Space Group & Reference \\
\hline rac-(1M)-biiq & VEMWOC & -90.96 & $I 4_{1} / \mathrm{a}$ & [108] \\
\hline rac-(1M)-8, $8^{\prime}-\mathrm{Me}_{2}$ biiq & GORTUC & -101.18 & $\mathrm{R}$ & [46] \\
\hline rac- $(1 M)-8,8^{\prime}-\mathrm{Me}_{2}$ biiq & GORTUC01 & -101.18 & $R \overline{3}$ & [45] \\
\hline rac-(1M)-8, $8^{\prime}-\mathrm{Et}_{2}$ biiq & GORVAK & 100.63 & $P b c a$ & [46] \\
\hline rac-(1M)-8, $8^{\prime}-\mathrm{Et}_{2}$ biiq & GORVAK01 & 100.63 & $P b c a$ & [45] \\
\hline rac- $(1 M)-4,4^{\prime}-(\mathrm{EtO})_{2}$ biiq & MUKDEC & -119.01 & $\mathrm{C} 2 / \mathrm{c}$ & [87] \\
\hline rac- $(1 M)-3,3,4,4^{\prime}-\left(4-\mathrm{MeOC}_{6} \mathrm{H}_{4}\right)_{2}$ biiq & RUKLUH & -124.67 & $P \overline{1}$ & [66] \\
\hline rac- $(1 M)-9$ & MOCWIL & 63.79 & $P 2_{1} / n$ & [54] \\
\hline
\end{tabular}

Table 2. Structurally characterized quaternized $1,1^{\prime}$-biisoquinolines and related species.

\begin{tabular}{|c|c|c|c|c|}
\hline Compound & Refcode & $\mathrm{N} 2-\mathrm{C} 1-\mathrm{C} 1^{\prime}-\mathrm{N} 2^{\prime} /^{\circ}$ & Space Group & Reference \\
\hline rac- $(1 M)-\left[\mathrm{H}_{2}\left(4,4^{\prime}-(\mathrm{HO})_{2}\right.\right.$ biiq $\left.)\right](\mathrm{Cl})_{2}$ & MUKDAY & 46.88 & $C 2 / c$ & [87] \\
\hline $\operatorname{rac}-(1 M)-(\mathbf{1 0})(\mathrm{I})_{2} \cdot \mathrm{H}_{2} \mathrm{O}$ & LALXUR & -107.81 & $A 2 / a$ & [110] \\
\hline rac- $(1 M)-(\mathbf{1 1})(\mathrm{Br})_{2}$ & KOTCAX & -37.23 & $I 4_{1} / a$ & [110] \\
\hline $\operatorname{rac}-(1 M)-(12)(\mathrm{Br})_{2} \cdot \mathrm{H}_{2} \mathrm{O}$ & KOTCEB & -59.74 & $P \overline{1}$ & [110] \\
\hline$(1 P)$-biiq $N, N^{\prime}$-dioxide & HIMGUF & 101.64 & $P 2_{1}$ & [98] \\
\hline
\end{tabular}

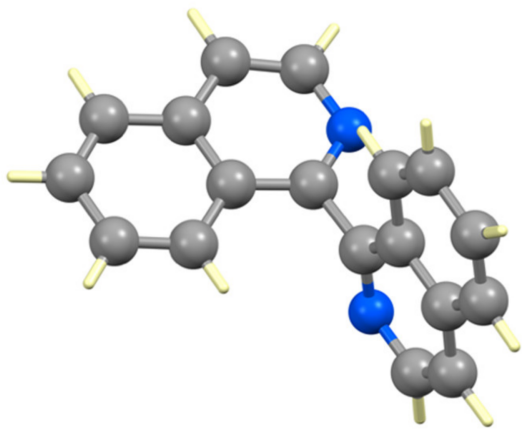

(a)

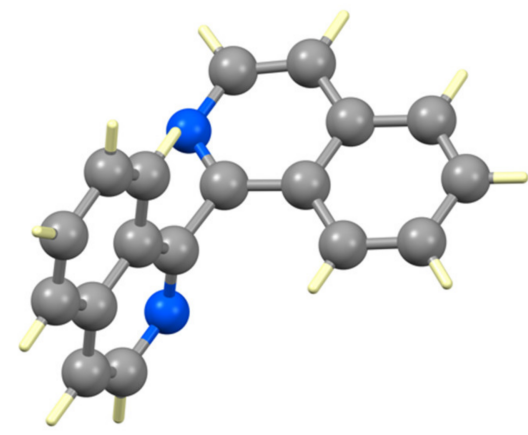

(b)

Figure 8. Both enantiomers of $1,1^{\prime}$-biisoquinoline are observed in the crystal structure of rac-biiq; (a) (1M)-biiq and (b) (1P)-biiq [108].

\subsection{Chiroptical and Spectroscopic Properties}

The absorption spectrum of the parent compound 3 in $\mathrm{EtOH}$ exhibits maxima at 218, 274, 284, 312 and $324 \mathrm{~nm}$ with absorption coefficients of 77,900, 7370, 6920, 6480 and $9430 \mathrm{M}^{-1} \mathrm{~cm}^{-1}$, respectively [41]. Various chiroptical correlations have been used to show that the (+)-forms of $1,1^{\prime}$-biisoquinolines possess the $(1 M)$ absolute configuration $[42,45,46,49-51,114]$

\section{Complexes of $\mathbf{1}, \mathbf{1}^{\prime}$-Biisoquinolines}

\subsection{A Note on Stereochemical Nomenclature}

In preparing this article, we became aware of the need to describe stereochemical arrangements in coordination entities containing multiple stereogenic features. Rigorous examination and consideration of the nomenclature challenges inherent in these situations has been limited, and the development and codification of required nomenclature has also lagged. As a consequence, ad hoc and mutually inconsistent approaches have been developed by individual research groups to address their particular needs [115-123]. It is clear 
that these situations are certainly not adequately covered in the standard recommendations from IUPAC $[20,124]$. This short section describes the approach we have adopted.

Although IUPAC defines the descriptors $\Delta$ and $\Lambda$ which describe the configuration of tris(bidentate) coordination entities, it neither tells you where to put the descriptor in the formula of the compound, nor the associated grammar (IR-9.3.4.1, IR-9.3.4.11, IR-9.3.4.12, IR-9.3.4.14) [124]. However, throughout the section dealing with stereochemical description of coordination entities (IR-9.3), the configuration index and other descriptors that relate to the configuration of ligands around the central atom are placed as prefixes to names and formulae. Due to this, and following general practice in the community, we prefer to place the configurational descriptors $\Delta$ and $\Lambda$ before the name or formula of the coordination entity. For consistency with organic nomenclature [20], we have placed stereochemical descriptors preceding a name or formula in enclosing marks. Thus, the two enantiomers of the $\left[\mathrm{Ru}(\mathrm{bpy})_{3}\right]^{2+}$ cation are denoted $(\Delta)-\left[\mathrm{Ru}(\mathrm{bpy})_{3}\right]^{2+}$ and $(\Lambda)-\left[\mathrm{Ru}(\mathrm{bpy})_{3}\right]^{2+}$ (Figure 9 ).

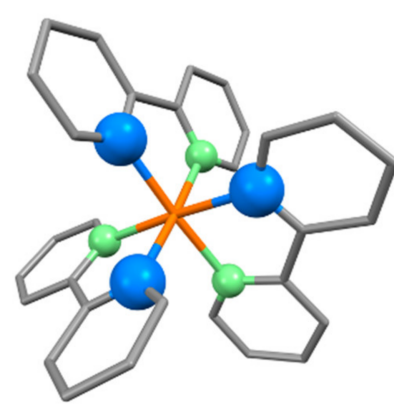

$\Delta$

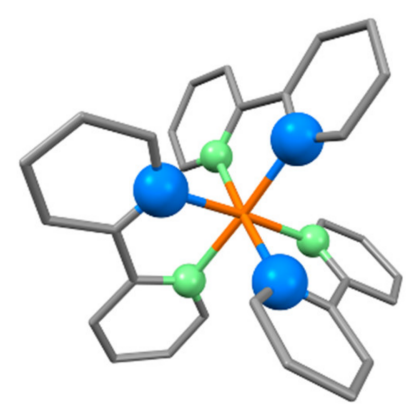

$\Lambda$

Figure 9. The absolute configurations of the two enantiomers of the $\left[\mathrm{Ru}(\mathrm{bpy})_{3}\right]^{2+}$ cation. The green atoms of each bpy ligand are further away from the observer, and the blue atoms are closer. The cation resembles a propeller, with each blade being defined by the donor atoms of the bpy ligands. An anti-clockwise rotation of the right-hand structure will "dig" the propeller into the page. This is the $\Lambda$-isomer. The mirror-image propeller on the left must be rotated clockwise to do so, and is the denoted $\Delta$-isomer.

A bulk material containing equal amounts of the two enantiomers of a compound is described as a racemate and can be denoted by the stereochemical descriptor rac- $(\mathrm{P}$ 91.2.1.1 [20]) combined with the stereodescriptor for the stereogenic site (P-93.1.3) [20]. The prefix rac- is defined as indicating the configuration of an entire molecule (P-93.1.3) [20]. This descriptor is particularly useful when applied to single crystals of materials in nonSohncke space groups which contain equal amounts of the two enantiomers. However, while we could use the notation $\mathrm{rac}-(\Delta)-\left[\mathrm{Ru}(\mathrm{bpy})_{3}\right]^{2+}$ as a description of a bulk material containing equal amounts of the $\Delta$ and $\Lambda$ enantiomers, we prefer the notation $(\Delta \Lambda)$ $\left[\mathrm{Ru}(\mathrm{bpy})_{3}\right]^{2+}$ for such simple systems.

Where a stereogenic center (or axis, or plane) is associated with a ligand in a coordination entity, we have adopted the convention of associating the appropriate stereochemical descriptors using standard IUPAC protocols with the ligand. Although there are arguments for placing all of the stereochemical descriptors before the coordination entity, it will not always be clear which descriptor is associated with which ligand. Thus, we will use $\{(1 M)$-biiq $\}$ and $\{(1 P)$-biiq $\}$ to represent the chirality of biiq ligands in coordination entities. If the bulk material contains equal amounts of $(1 M)$-biiq and (1P)-biiq we use the notation $\{(1 M P)$-biiq\}. Remember that the term racemic refers to a property of a molecule or coordination entity as a whole: thus, the free ligand could be described as rac-(1M)-biiq but this notation should not be used within a formula for a related complex.

The question of relative stereochemistry is more complex and we enter terra incognita in the context of coordination entities. IUPAC has yet to examine and codify the ways of representing and distinguishing the subtly different stereochemical situations that are possible in these complex systems. 
Consider the complex cation $\left[\mathrm{Ru}(\mathrm{biiq})_{3}\right]^{2+}$, where this formulation encompasses any or all of the set of eight stereoisomers (four diastereoisomers and their enantiomers)

- $(\Delta)-\left[\operatorname{Ru}\{(1 M) \text {-biiq }\}_{3}\right]^{2+}$ and $(\Lambda)-\left[\operatorname{Ru}\{(1 P) \text {-biiq }\}_{3}\right]^{2+}$

- $\quad(\Delta)-\left[\operatorname{Ru}\{(1 M) \text {-biiq }\}_{2}\{(1 P) \text {-biiq }\}\right]^{2+}$ and $(\Lambda)-\left[\operatorname{Ru}\left\{(1 M) \text {-biiq }\{(1 P) \text {-biiq }\}_{2}\right]^{2+}\right.$

- $\quad(\Delta)-\left[\operatorname{Ru}\{(1 M) \text {-biiq }\}\{(1 P) \text {-biiq }\}_{2}\right]^{2+}$ and $(\Lambda)-\left[\operatorname{Ru}\{(1 M) \text {-biiq }\}_{2}\{(1 P) \text {-biiq }\}\right]^{2+}$

- $\quad(\Lambda)-\left[\operatorname{Ru}\{(1 M) \text {-biiq }\}_{3}\right]^{2+}$ and $(\Delta)-\left[\operatorname{Ru}\{(1 P) \text {-biiq }\}_{3}\right]^{2+}$

In a formula, $\{(1 M P)$-biiq $\}$ means that the biiq ligand is present in equal numbers in the bulk material with $1 M$ or $1 P$ chirality. This will not necessarily be the case in diastereoisomers and we need a notation for a ligand which may possess either chirality, but not necessarily with equal numbers with $1 M$ or $1 P$ chirality. This we denote in a formula as $\{(1 M / 1 P)$-biiq\}. Similarly, $\Delta \Lambda$ denotes equal amounts of the $\Delta$ and $\Lambda$ configurations, whereas $\Delta / \Lambda$ will be used for not necessarily equal amounts of either configuration, being present.

The racemate of a particular diastereoisomer is represented by adding the rac- descriptor in front of a formula or name of a defined stereoisomer, so that $r a c-(\Delta)-[\operatorname{Ru}\{(1 M)-$ biiq $\left.\}_{3}\right]^{2+}$ refers to equal amounts of $(\Delta)-\left[\operatorname{Ru}\{(1 M) \text {-biiq }\}_{3}\right]^{2+}$ and $(\Lambda)-\left[\operatorname{Ru}\{(1 P) \text {-biiq }\}_{3}\right]^{2+}$ being present. Note that rac- refers to the pairwise inversion of all of the stereogenic centers in a coordination entity. In principle, the racemate can also be defined using pairwise (or higher) groups of descriptors. Thus, $(\Delta \Lambda)-\left[\operatorname{Ru}\{(1 M P) \text {-biiq }\}_{3}\right]^{2+}$ refers to the mixture of $(\Delta)-\left[\operatorname{Ru}\{(1 M) \text {-biiq }\}_{3}\right]^{2+}$ and $(\Lambda)-\left[\operatorname{Ru}\{(1 P) \text {-biiq }\}_{3}\right]^{2+}$ being present. The order of symbols, for example in $\Delta \Lambda$ and $M P$, is significant in defining relative configurations of different stereogenic features (centers, axes, etc.) that are present in a particular diastereoisomer. $(\Delta \Lambda)-\left[\operatorname{Ru}\{(1 M P)-\text { biiq }\}_{3}\right]^{2+}$ and $(\Delta \Lambda)-\left[\operatorname{Ru}\{(1 P M) \text {-biiq }\}_{3}\right]^{2+}$, where the order of the ligand descriptors is reversed, refer to racemic mixtures of different diastereoisomers: rac- $(\Delta)$ $\left[\operatorname{Ru}\{(1 M) \text {-biiq }\}_{3}\right]^{2+}$ and $r a c-(\Delta)-\left[\operatorname{Ru}\{(1 P) \text {-biiq }\}_{3}\right]^{2+}$, respectively. The potential for confusion in keeping track of the relative configurations that are present in a particular diastereoisomer, particularly when the descriptors are located in different parts of the formula or name, is a key reason for preferring the rac-descriptor over $(\Delta \Lambda)$ for systems where multiple diastereo-isomers are possible. Overall, these usages are best clarified with a few examples:

- $\quad(\Delta)-\left[\operatorname{Ru}\{(1 M) \text {-biiq }\}_{3}\right]^{2+}$ denotes a single enantiomer of a single diastereoisomer;

- $\quad r a c-(\Delta)-\left[\operatorname{Ru}\{(1 M)-b i i q\}_{3}\right]^{2+}$ denotes a racemic mixture of a single diastereoisomer (i.e., equal amounts of $(\Delta)-\left[\operatorname{Ru}\{(1 M) \text {-biiq }\}_{3}\right]^{2+}$ and $\left.(\Lambda)-\left[\operatorname{Ru}\{(1 P)-\text { biiq }\}_{3}\right]^{2+}\right)$;

- $\quad r e l-(\Delta)-\left[\operatorname{Ru}\{(1 M)-\text { biiq }\}_{3}\right]^{2+}$ denotes a mixture but not necessarily equal amounts of the two enantiomers of a single diastereoisomer: $(\Delta)-\left[\operatorname{Ru}\{(1 M) \text {-biiq }\}_{3}\right]^{2+}$ and $(\Lambda)$ $\left[\operatorname{Ru}\{(1 P) \text {-biiq }\}_{3}\right]^{2+}$;

- $\quad(\Delta / \Lambda)$ - $\left[\operatorname{Ru}\{(1 M) \text {-biiq }\}_{3}\right]^{2+}$ denotes variable amounts of the two diastereoisomers $(\Delta)$ $\left[\operatorname{Ru}\{(1 M)-\text { biiq }\}_{3}\right]^{2+}$ and $(\Lambda)-\left[\operatorname{Ru}\{(1 M) \text {-biiq }\}_{3}\right]^{2+}$;

- $(\Delta \Lambda)-\left[\operatorname{Ru}\{(1 M) \text {-biiq }\}_{3}\right]^{2+}$ denotes a 1:1 mixture of the diastereoisomers $(\Delta)-[\operatorname{Ru}\{(1 M)$ biiq $\left.\}_{3}\right]^{2+}$ and $(\Lambda)-\left[\operatorname{Ru}\{(1 M) \text {-biiq }\}_{3}\right]^{2+}$;

- $\quad(\Delta)-\left[\operatorname{Ru}\{(1 M P) \text {-biiq }\}_{3}\right]^{2+}$ denotes the mixture of diastereoisomers $(\Delta)-\left[\operatorname{Ru}\{(1 M) \text {-biiq }\}_{3}\right]^{2+}$, $(\Delta)-\left[\operatorname{Ru}\{(1 M) \text {-biiq }\}_{2}\{(1 P) \text {-biiq }\}\right]^{2+},(\Delta)-\left[\operatorname{Ru}\{(1 M) \text {-biiq }\}\{(1 P) \text {-biiq }\}_{2}\right]^{2+}$ and $(\Delta)-[\operatorname{Ru}\{(1 P)-$ biiq $\left._{3}\right]^{2+}$ in which the total numbers of $(1 M)$-biiq and (1P)-biiq ligands in the bulk material are identical. This does not imply equal amounts of the different diastereoisomers;

- $(\Delta)-\left[\operatorname{Ru}\{(1 M / 1 P)-\text { biiq }\}_{3}\right]^{2+}$ denotes a mixture of diastereoisomers $(\Delta)-\left[\operatorname{Ru}\{(1 M) \text {-biiq }\}_{3}\right]^{2+}$, $(\Delta)-\left[\operatorname{Ru}\{(1 M) \text {-biiq }\}_{2}\{(1 P) \text {-biiq }\}\right]^{2+},(\Delta)-\left[\operatorname{Ru}\{(1 M) \text {-biiq }\}\{(1 P) \text {-biiq }\}_{2}\right]^{2+}$, and $(\Delta)-[\operatorname{Ru}\{(1 P)-$ biiq $\left.\}_{3}\right]^{2+}$ in which the total amount of $(1 M)$-biiq and (1P)-biiq ligands is variable;

- $(\Delta / \Lambda)-\left[\operatorname{Ru}\{(1 M P) \text {-biiq }\}_{3}\right]^{2+}$ denotes the mixture of eight stereoisomers listed earlier in which the total numbers of $(1 M)$-biiq and (1P)-biiq ligands are identical but the numbers of $\Delta$ and $\Lambda$ stereogenic centers may be different;

- $(\Delta \Lambda)-\left[\operatorname{Ru}\{(1 M / 1 P)-\text { biiq }\}_{3}\right]^{2+}$ denotes the mixture of eight stereoisomers listed earlier in which the total numbers of (1M)-biiq and (1P)-biiq ligands are variable but the numbers of $\Delta$ and $\Lambda$ stereogenic centers are identical 
- $(\Delta / \Lambda)-\left[\operatorname{Ru}\{(1 M / 1 P) \text {-biiq }\}_{3}\right]^{2+}$ denotes the mixture of eight diastereoisomers listed earlier in which the total numbers of (1M)-biiq and (1P)-biiq ligands and $\Delta$ and $\Lambda$ stereogenic centers are freely variable.

The reaction of rac-(1M)-biiq with an achiral iron(II) salt will generate rac- $(\Delta)-[\mathrm{Fe}\{(1 \mathrm{M})$ -

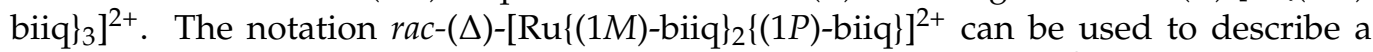
racemic mixture of the two enantiomers $(\Delta)-\left[\operatorname{Ru}\{(1 M) \text {-biiq }\}_{2}\{(1 P) \text {-biiq }\}\right]^{2+}$ and $(\Lambda)-[\operatorname{Ru}\{(1 M)$ biiq\} $\left.\{(1 P)-\text { biiq }\}_{2}\right]^{2+}$. We also note that the use of the prefix rel- (P-93.1.4) [20] in rel-( $\Delta$ )$\left[\operatorname{Ru}\{(1 M) \text {-biiq }\}_{2}\{(1 P) \text {-biiq }\}\right]^{2+}$ is not equivalent as it does not imply equal amounts of the compounds.

This leads to descriptions such as $(\Delta)-\left[\operatorname{Ru}\{(1 P) \text {-biiq }\}(\text { bpy })_{2}\right]^{2+}$ for an enantiopure diastereoisomer and $(\Delta \Lambda)-\left[\operatorname{Ru}\{(1 P) \text {-biiq }\}(\text { bpy })_{2}\right]^{2+}$ for a 1:1 mixture of the diastereoisomers $(\Delta)$ - $\left[\operatorname{Ru}\{(1 P) \text {-biiq }\}(\text { bpy })_{2}\right]^{2+}$ and $(\Lambda)-\left[\operatorname{Ru}\{(1 P) \text {-biiq }\}(\text { bpy })_{2}\right]^{2+}$. Using the proposal for the use of rac-above, the enantiomeric pair $(\Delta)-\left[\operatorname{Ru}\{(1 P) \text {-biiq }\}(\text { bpy })_{2}\right]^{2+}$ and $(\Lambda)-[\operatorname{Ru}\{(1 M)$ biiq $\left.\}(\text { bpy })_{2}\right]^{2+}$ can be denoted rac- $(\Delta)-\left[\operatorname{Ru}\{(1 P) \text {-biiq }\}(\text { bpy })_{2}\right]^{2+}$. The formulae $(\Delta \Lambda)-[\operatorname{Ru}\{(1 M P)-$ biiq $\left.\}(\text { bpy })_{2}\right]^{2+}$ and $(\Delta / \Lambda)-\left[\operatorname{Ru}\{(1 M / 1 P) \text {-biiq }\}(\text { bpy })_{2}\right]^{2+}$ describes mixtures of multiple diastereoisomers and not a single enantiomeric pair. We contemplated extending this notation to the use of ambo- (P-93.1.4) [20] - but our heads exploded!

The set of notations described above will be used where the stereochemical properties of the complexes are known or are of interest. Where no stereochemical information is known or implied, we simply use the abbreviation biiq.

\subsection{Group 7}

The complex $\left[\operatorname{Re}\{(1 M P)\right.$-biiq $\left.)(\mathrm{CO})_{3} \mathrm{Cl}\right] \cdot \mathrm{PhMe}$ has been structurally characterized (Figure 10) and has the expected octahedral structure with two carbonyl ligands trans to the biiq $N$-donor atoms (CSD Refcode AYUPER, space group P $\overline{1}$ ) [125]. The lattice comprises equal numbers of complex molecules with (1M)-biiq and (1P)-biiq ligands with an $\mathrm{N} 2-\mathrm{C} 1-\mathrm{C}^{\prime}-\mathrm{N} 2^{\prime}$ torsion angle of $-27.48^{\circ}$. Electrospray mass spectrometric (MS) studies of methanol solutions containing $\left[\operatorname{Re}(\mathrm{acac})_{2}(\mathrm{Cl})\left(\mathrm{PPh}_{3}\right)\right]$ and biiq exhibited an ion assigned to the species $\left\{\operatorname{Re}(\mathrm{biiq})\left(\mathrm{PPh}_{3}\right)\right\}^{+}[126]$.

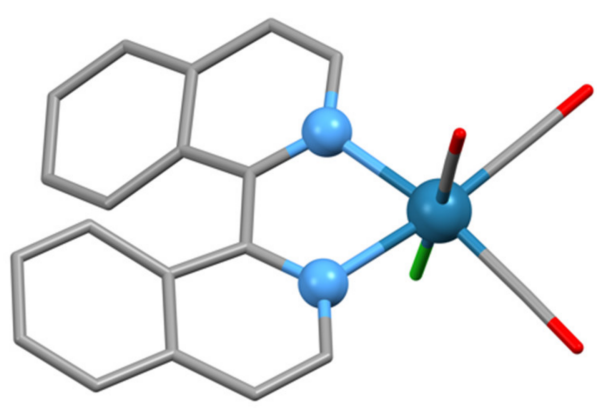

Figure 10. The structure of the $\left[\operatorname{Re}\{(1 M)\right.$-biiq $\left.)(\mathrm{CO})_{3} \mathrm{Cl}\right]$ molecule found in the lattice of $[\operatorname{Re}\{(1 M P)$ biiq) $\left.(\mathrm{CO})_{3} \mathrm{Cl}\right] \cdot \mathrm{PhMe}$. Hydrogen atoms have been omitted for clarity and the metal and nitrogen donor atoms are represented as balls.

\subsection{Group 8}

In the first paper describing the synthesis of biiq, Case reported that the compound did not give a typical ferroin coloration on treatment with iron(II) salts [81]. It was only many years later that iron complexes of biiq and its derivatives were prepared and characterized. The blue-green spin-crossover complexes $\left[\mathrm{Fe}(\mathrm{biiq})_{3}\right] \mathrm{X}_{2} \cdot 2.5 \mathrm{H}_{2} \mathrm{O}\left(\mathrm{X}=\mathrm{BF}_{4}, \mathrm{ClO}_{4}\right)$ are obtained directly from the reaction of biiq with the appropriate iron(II) salts [77]. Detailed magnetic and Mössbauer data for the compounds were reported, consistent with thermal population of the ${ }^{5} T_{2}$ state from the ${ }^{1} A_{1}$ ground state at higher temperatures. As might be expected for a sterically hindered heterocyclic diimine ligand, there is appreciable dissociation in acetone solutions of the complexes [77] and no complex ions were reported in electrospray MS studies of methanol solutions containing iron(II) chloride and biiq [126]. The complex 
$\left[\mathrm{Fe}_{2}\left(\mathrm{H}_{2} \mathrm{O}\right)_{2}\left\{6,6^{\prime}, 7,7^{\prime}-(\mathrm{MeO})_{4} \text { biiq }\right\}_{4}(\mu-\mathrm{O})\right] \mathrm{Cl}_{4} \cdot 4 \mathrm{H}_{2} \mathrm{O}$ is reported to be an effective catalyst for the selective oxidation of primary and secondary alcohols to aldehydes and ketones, respectively [127].

The complex cation $\left[\mathrm{Ru}\left(\text { biiq) }(\mathrm{bpy})_{2}\right]^{2+}\right.$ was first described by Ashby et al. who also reported the solid-state structure of rac- $(\Delta)-\left[\mathrm{Ru}\{(1 P)\right.$-biiq $\left.\}(\mathrm{bpy})_{2}\right]\left(\mathrm{PF}_{6}\right)_{2}(\mathrm{CSD}$ Refcode HAKPEO, HAKPEO10, space group $\mathrm{C} 2 / c$, Figure $11 \mathrm{a}, \mathrm{N} 2-\mathrm{C} 1-\mathrm{C}^{\prime}-\mathrm{N} 2^{\prime}$ torsion angles of $\left.177.73,-24.12^{\circ}\right)$ [128]. In the solid state, the two diastereoisomers $(\Delta)-[\operatorname{Ru}\{(1 P)-$ biiq\}(bpy $\left.)_{2}\right]\left(\mathrm{PF}_{6}\right)_{2}$ and $(\Lambda)-\left[\operatorname{Ru}\{(1 M)\right.$-biiq $\left.\}(\text { bpy })_{2}\right]\left(\mathrm{PF}_{6}\right)_{2}$ are present in the lattice (Ashby described the conformation of the chelate ring in terms of the $\lambda$ and $\delta$ description for ethane-1,2-diamine chelate rings with $\lambda$ corresponding to $1 M$ and $\delta$ to $1 P$ ) (Figure $11 \mathrm{~b}$ ). Clemente has published a correction to the space group and a re-refinement of the structure reported (CSD Refcode HAKPEO11, space group Ibca, N2-C1-C1'-N2' torsion angle of $-24.14^{\circ}$ ) [129]. When the crystalline material is dissolved in $\mathrm{CD}_{3} \mathrm{COCD}_{3}$ at room temperature a 3:1 mixture of diastereoisomers $\left((\Delta)-\left[\operatorname{Ru}\{(1 P)-(\text { biiq })\}(\text { bpy })_{2}\right]^{2+}+(\Lambda)-[\operatorname{Ru}\{(1 M)-\right.$ (biiq) $\left.\left.\}(\text { bpy })_{2}\right]^{2+}:(\Lambda)-\left[\operatorname{Ru}\{(1 P)-(\text { biiq })\}(\text { bpy })_{2}\right]^{2+}+(\Delta)-\left[\operatorname{Ru}\{(1 M)-(\text { biiq })\}(\text { bpy })_{2}\right]^{2+}\right)$ is observed in the ${ }^{1} \mathrm{H}$ NMR spectrum, whereas dissolution at $-80{ }^{\circ} \mathrm{C}$ gives a solution showing only the major pair of enantiomers. In solution, the related compound $r a c-(\Delta)-[\operatorname{Ru}\{(1 P)-$ biiq\}(phen $\left.)_{2}\right]\left(\mathrm{PF}_{6}\right)_{2}$ is reported to exhibit two diastereoisomers in a 2:1 ratio [130]. The major and minor diastereoisomers of $\left[\mathrm{Ru}(\text { biiq })(\mathrm{bpy})_{2}\right]^{2+}$ interconvert at $80^{\circ} \mathrm{C}$. The original report by Ashby excluded Bailar and Rây-Dutt twisting mechanisms for the interconversion and it was suggested that one of the two biiq $\mathrm{Ru}-\mathrm{N}$ bonds was broken, followed by either rotation about the $\mathrm{C} 1-\mathrm{C}^{\prime}$ bond or a turnstile rotation, although isomerization via a planar biiq could not be excluded [128]. In a subsequent publication, the authors concluded that a monodentate biiq could not be involved, because the rate of racemization of $\left[\mathrm{Ru}\right.$ (biiq) $\left.(\mathrm{bpy})_{2}\right] \mathrm{Cl}_{2}$ in $\mathrm{D}_{2} \mathrm{O}$ was essentially the same in the presence of $1 \mathrm{M} \mathrm{DCl}$ and $1 \mathrm{M} \mathrm{LiCl}$ and they proposed a transition state involving a bidentate planar biiq [72]. The authors extended the study to rac- $(\Delta)$-[Os $\{(1 P)$-biiq $\left.\}(\text { bpy })_{2}\right]\left(\mathrm{PF}_{6}\right)_{2}$ which was crystallographically characterized (CSD Refcode YONHUE, space group $\mathrm{C} 2 / \mathrm{c}, \mathrm{N} 2-\mathrm{C} 1-\mathrm{C}^{\prime}-\mathrm{N} 2^{\prime}$ torsion angle $-20.14^{\circ}$ ) and shown to exhibit the same favored diastereoisomers as the ruthenium analog in the solid state. Comparison of the rates of racemization for the ruthenium $\left(\Delta \mathrm{G}^{\ddagger}\right.$ major $\rightarrow$ minor $79 \mathrm{~kJ} \mathrm{~mol}^{-1}$ at $323 \mathrm{~K}$ ) and osmium ( $\Delta \mathrm{G}^{\ddagger}$ major->minor $72 \mathrm{~kJ} \mathrm{~mol}^{-1}$ at $323 \mathrm{~K}$ ) supported the proposal of the stabilization of a planar transition state as the strength of the $\mathrm{M}-\mathrm{N}$ bond is expected to increase rather than decrease on descending the triad [131]. The space group of rac$(\Delta)$-[Os $\{(1 P)$-biiq $\left.\}(\text { bpy })_{2}\right]\left(\mathrm{PF}_{6}\right)_{2}$ has been revised by Clemente (CSD Refcode YONHUE01, space group $\mathrm{Ibca}, \mathrm{N} 2-\mathrm{C} 1-\mathrm{C}^{\prime}-\mathrm{N} 2^{\prime}$ torsion angle $\left.-20.15^{\circ}\right)$ [129]

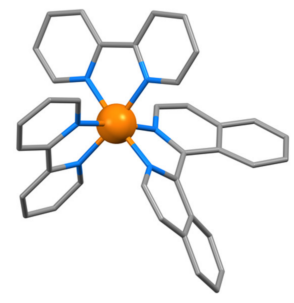

(a)

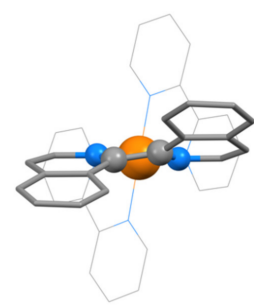

(b)

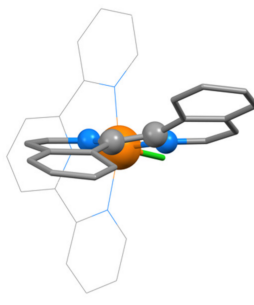

(c)

Figure 11. (a) The structure of the $(\Lambda)-\left[\operatorname{Ru}\{(1 M)-(\text { biiq })\}(\text { bpy })_{2}\right]^{2+}$ cation found in $r a c-(\Delta)-[\operatorname{Ru}\{(1 P)-$ (biiq) $\left.\}(\text { bpy })_{2}\right]\left(\mathrm{PF}_{6}\right)_{2}$ with hydrogen atoms omitted for clarity The lattice also contains the enantiomeric $(\Delta)-\left[\operatorname{Ru}\{(1 P)-(\text { biiq })\}(\text { bpy })_{2}\right]^{2+}$ cation; (b) a projection of the $(\Lambda)-\left[\operatorname{Ru}\{(1 M)-(\text { biiq })\}(\text { bpy })_{2}\right]^{2+}$ cation in the $\mathrm{N}-\mathrm{Ru}-\mathrm{N}$ showing the positioning of $\mathrm{C} 1$ and $\mathrm{C}^{\prime}$ above and below this plane. The bpy ligands are rendered as wireframe, the biiq as capped sticks and the five atoms defining the chirality of the chelate ring as balls, and all hydrogen atoms have been omitted for clarity; (c) the $[\mathrm{Os}\{(1 M) \text {-biiq }\} \mathrm{Cl}(\mathrm{tpy})]^{+}$ cation present in single crytsals obtained from rac-([Os $\{(1 M P)-$ biiq $\} \mathrm{Cl}($ tpy $)] \mathrm{Cl} \cdot \mathrm{H}_{2} \mathrm{O}$; the compound crystallized in homochiral crystals (all $1 M$ or all $1 P$ ) in the space group $P 2_{1} 2_{1} 2_{1}$. The tpy ligand is rendered as wireframe, the biiq as capped sticks and the five atoms defining the chirality of the chelate ring as balls and all hydrogen atoms have been omitted for clarity. 
The same phenomenon was also observed in the compounds $\left[\mathrm{M}\{(1 M P)-b i i q\}\left(\eta^{6}\right.\right.$ $\left.\left.\mathrm{C}_{6} \mathrm{H}_{6}\right) \mathrm{X}\right]\left(\mathrm{PF}_{6}\right)(\mathrm{M}=\mathrm{Ru}, \mathrm{Os} ; \mathrm{X}=\mathrm{Cl}, \mathrm{I})$ and solid state structures were reported for $[\mathrm{M}\{(1 M P)-$ biiq\} $\left.\left(\eta^{6}-\mathrm{C}_{6} \mathrm{H}_{6}\right) \mathrm{Cl}\right]\left(\mathrm{PF}_{6}\right)\left(\mathrm{M}=\mathrm{Ru}\right.$, CSD Refcode QEWRAL, space group $P \overline{1}, \mathrm{~N} 2-\mathrm{C} 1-\mathrm{C} 1^{\prime}-\mathrm{N} 2^{\prime}$ torsion angle $-26.97^{\circ} ; \mathrm{M}=\mathrm{Os}$, CSD Refcode QEWREP, space group $P \overline{1}, \mathrm{~N} 2-\mathrm{C} 1-\mathrm{C} 1^{\prime}-\mathrm{N} 2^{\prime}$ torsion angle $-26.47^{\circ}$ ) [132]. The racemization mechanism involving a planar biiq ligand was invoked (Scheme 3) and the independence from the ancillary ligands established by showing a similar mechanism for the compounds $\left[\mathrm{M}\{(1 M P)-b i i q\}\left(\eta^{6}-\mathrm{C}_{6} \mathrm{H}_{6}\right) \mathrm{X}\right]\left(\mathrm{PF}_{6}\right)$ $(\mathrm{M}=\mathrm{Ru}, \mathrm{Os} ; \mathrm{X}=\mathrm{Cl}, \mathrm{I})[132]$ and $[\mathrm{M}\{(1 M P)$-biiq $\} \mathrm{Cl}(\mathrm{tpy})]\left(\mathrm{PF}_{6}\right)\left(\mathrm{M}=\mathrm{Ru}, \mathrm{Os} ;\right.$ tpy $=2,2^{\prime}: 6^{\prime}, 2^{\prime \prime}$ terpyridine) [133]. The mechanism is of interest as an example of an inverse free-energy relationship in which the $\mathrm{M}-\mathrm{N}$ bonds to the biiq ligand are stronger in the planar transition state than in the thermodynamically favored forms. Molecular mechanics parameters for ruthenium(II) oligopyridine and related compounds have been developed (MM3* force field in MacroModel combined with B3LYP frequency calculations) and the energy difference between the diastereoisomers $(\Delta)-\left[\operatorname{Ru}\{(1 P)-(\text { biiq })\}(\text { bpy })_{2}\right]^{2+}$ and $(\Lambda)-[\operatorname{Ru}\{(1 P)-$ (biiq) $\}(\text { bpy })_{2} \mathrm{~J}^{2+}$ was calculated to be $3.0 \mathrm{~kJ} \mathrm{~mol}^{-1}$ in good accord with the experimental value of $2.7 \mathrm{~kJ} \mathrm{~mol}^{-1}$ [134]. Although the calculated energy of the planar transition state $\left(100 \mathrm{~kJ} \mathrm{~mol}^{-1}\right)$ implied in Scheme 3 was higher than the experimental value $\left(70 \mathrm{~kJ} \mathrm{~mol}^{-1}\right)$, the method confirmed that coordination of biiq to ruthenium lowers the isomerization barrier for a mechanism involving a planar intermediate [134]. The complexes [ $\left.\mathrm{Ru}(\mathrm{biiq})_{2} \mathrm{Cl}_{2}\right]$ and $\left[\mathrm{RuL}_{2}\left(\mathrm{~L}^{\prime}\right)\right]\left(\mathrm{ClO}_{4}\right)_{2}\left(\mathrm{~L}=\right.$ bpy, phen, $\mathrm{L}^{\prime}=$ biiq; $\mathrm{L}=$ biiq, $\mathrm{L}^{\prime}=$ bpy, phen $)$ and $\left.\left[\mathrm{Ru}(\text { biiq })_{3}\right)\right]\left(\mathrm{ClO}_{4}\right)_{2}$ have been prepared and their spectroscopic properties reported [135]. Solutions of salts of the complex cations $\left.\left[\mathrm{Ru}(\text { biiq })_{3}\right)\right]^{2+},\left[\mathrm{Ru}(\text { biiq })_{2}(\text { bpy })\right]^{2+}$ and $\left[\mathrm{Ru}(\text { biiq })(\text { bpy })_{2}\right]^{2+}$ in aqueous silver sol exhibit strong surface-enhanced resonance Raman scattering upon excitation in the MLCT bands. It is unfortunate that information was given neither on the diastereoisomers present nor on the anions, as these are expected to have a significant effect on this phenomenon [136]. Starke has reported some unusual collision-induced dissociation (CID) studies of homo- and heteroleptic ruthenium complexes with biiq ligands although from the formulations it is not clear exactly what complexes were studied [126].<smiles></smiles>

(1P)-biiq $\left(1 S_{\mathrm{a}}\right)$-biiq MISDIRECTED

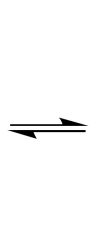

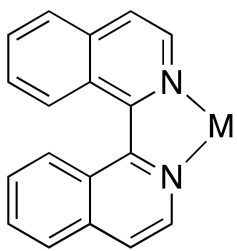

achiral planar

DIRECTED<smiles></smiles>

$(1 M)$-biiq

$\left(1 R_{\mathrm{a}}\right)$-biiq

\section{MISDIRECTED}

Scheme 3. The mechanism proposed by Ashby for the racemization of coordinated 1,1'-biisoquinoline ligands. The term "misdirected" refers to the fact that the pair of vectors describing the orientation of the nitrogen lone pairs in the plane of the quinoline ring is not optimal for binding to the metal center. The various descriptions used for the chirality of the coordinated biiq ligands are also indicated.

The barrier to inversion of the coordinated biiq ligand relates primarily to the steric interaction between the $\mathrm{H} 8$ and $\mathrm{H} 8^{\prime}$ atoms as well as the nitrogen lone pairs in the planar form. The conformation of the biiq ligand in its complexes can be seen as a balance between minimizing the $\mathrm{H} 8-\mathrm{H} 8^{\prime}$ interactions (non-planar) and maximizing the $\mathrm{M}-\mathrm{N}$ interactions (planar). Support for this comes from the observation that rac- $\left[\mathrm{Ru}(\mathrm{biiq})(\mathrm{bpy})_{2}\right]\left(\mathrm{PF}_{6}\right)_{2}$ is cleanly converted to $\left[\mathrm{Ru}(\mathrm{bpy})_{2}(\mathrm{dap})\right]\left(\mathrm{PF}_{6}\right)_{2}$ (dap $=1$,12-diazaperylene) upon heating to $175-195{ }^{\circ} \mathrm{C}$ in $\mathrm{HOCH}_{2} \mathrm{CH}_{2} \mathrm{OH}-\mathrm{Me}_{2} \mathrm{CO}$ in the presence of Pd-C (Scheme 4) [137]. 


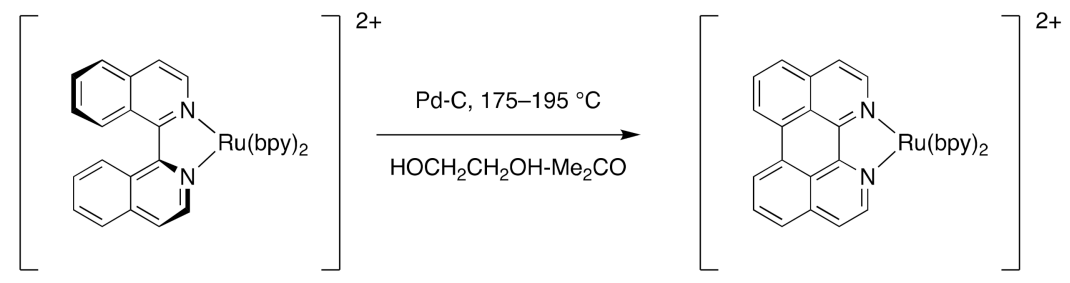

Scheme 4. The steric interactions between $\mathrm{H} 8$ and $\mathrm{H}^{\prime}$ in the coordinated biiq ligand in $\left[\mathrm{Ru}\right.$ (biiq) $\left(\mathrm{bpy}_{2}\right]\left(\mathrm{PF}_{6}\right)_{2}$ enables a facile dehydrogenation to generate a coordinated dap ligand in the complex $\left[\mathrm{Ru}(\mathrm{bpy})_{2}(\mathrm{dap})\right]\left(\mathrm{PF}_{6}\right)_{2}$.

The solid-state structures of $[\mathrm{Os}\{(1 M)$-biiq $\} \mathrm{Cl}(\mathrm{tpy})] \mathrm{Cl} \cdot \mathrm{H}_{2} \mathrm{O}$ (CSD Refcode ACUDEH, Space group $P 2{ }_{1} 2_{1} 2{ }_{1}, \mathrm{~N} 2-\mathrm{C} 1-\mathrm{C} 1^{\prime}-\mathrm{N} 2^{\prime}$ torsion angle $-21.01^{\circ}$, Figure 11c) [133] and [Ru\{(1MP)-biiq $\} \mathrm{Cl}($ tpy) $]\left(\mathrm{ClO}_{4}\right) \cdot \mathrm{CH}_{3} \mathrm{CN}$ (CSD Refcode YEZBEK, space group $P 2_{1} / c$, N2$\mathrm{C} 1-\mathrm{C} 1^{\prime}-\mathrm{N} 2^{\prime}$ torsion angle $\left.22.18^{\circ}\right)$ [138] have been reported. The complex [ $\mathrm{Ru}(\mathrm{biiq})(\mathrm{O})\left(\mathrm{Me}_{3}-\right.$ TACN $)]\left(\mathrm{ClO}_{4}\right)\left(\mathrm{Me}_{3} \mathrm{TACN}=1,4,7\right.$-trimethyl-1,4,7-triazacyclononane $)$ is effective in the stoichiometric oxidation of alkenes to epoxides [139]. The compound [Ru(biiq)(phen $\left.)_{2}\right]\left(\mathrm{PF}_{6}\right)_{2}$ is very photostable and is only converted to $\left[\mathrm{Ru}(\mathrm{MeCN})_{2}(\mathrm{phen})_{2}\right]\left(\mathrm{PF}_{6}\right)_{2}$ after several hours of irradiation with a $250 \mathrm{~W}$ halogen lamp [130].

A series of compounds including $\left[\mathrm{Ru}_{2}(\mathrm{biiq})_{2}(\mathrm{CO})_{4}(\mu-\mathrm{OAc})\right](\mathrm{OAc}),\left[\mathrm{Ru}(\mathrm{biiq}) \mathrm{Cl}\left(\eta^{6}-p-\right.\right.$ cymene) $] \mathrm{Cl}$ and $\left[\mathrm{Ru}\right.$ (biiq) $\mathrm{Cl}\left(\eta^{6}-p\right.$-cymene $\left.)\right]\left(\mathrm{BPh}_{4}\right)$ has been prepared and shown to be effective catalysts for the hydrogenation of alkenes [74]. The homoleptic compound $\left[\mathrm{Ru}(\mathrm{biiq})_{3}\right]\left(\mathrm{PF}_{6}\right)_{2}$ was also obtained in this work. The solid-state structure of $[\mathrm{Ru}\{(1 M P)-$ biiq)Cl( $\eta^{6}$-p-cymene)](BPh 4$)\left(\mathrm{CSD}\right.$ Refcode GABGUM, space group $P 2_{1} / n, \mathrm{~N} 2-\mathrm{C} 1-\mathrm{C} 1^{\prime}-\mathrm{N} 2^{\prime}$ torsion angle of $-24.78^{\circ}$ ) [74] was also reported and the cation shown to be broadly similar to the $\left[\mathrm{M}(\mathrm{biiq}) \mathrm{Cl}\left(\eta^{6}-\mathrm{C}_{6} \mathrm{H}_{6}\right)\right]^{+}(\mathrm{M}=\mathrm{Ru}, \mathrm{Os})$ cations previously described [132].

When the complexes $\left[\mathrm{Ru}(\mathrm{acac})_{2} \mathrm{~L}\right]\left(\mathrm{ClO}_{4}\right)_{n}$ ( $\mathrm{L}=3,4$-dihydro-1, $1^{\prime}$-biisoquinoline or $3,3^{\prime}, 4,4^{\prime}$-tetrahydro-1, $1^{\prime}$-biisoquinoline, $n=0$ or 1 ) are treated with $\mathrm{NEt}_{3}$ under aerobic conditions, the ligands are fully aromatized and the compounds $\left[\mathrm{Ru}(\mathrm{acac})_{2}(\mathrm{biiq})\right]\left(\mathrm{ClO}_{4}\right)_{n}$ $(\mathrm{n}=0$ or 1$)$ are obtained [140]. The complex rac- $(\Delta)-\left[\mathrm{Ru}(\mathrm{acac})_{2}\{(1 M)\right.$-biiq $\left.\}\right]\left(\mathrm{ClO}_{4}\right)$ has been structurally characterized (CSD Refcode OGIVEI, space group $P 2 / n$, Figure 12a, $\mathrm{N} 2-\mathrm{C} 1-\mathrm{Cl}^{\prime}-\mathrm{N} 2^{\prime}$ torsion angle of $\left.25.38^{\circ}\right)$. The lattice contains equal numbers of the two diastereoisomeric cations $(\Delta)-\left[\mathrm{Ru}(\mathrm{acac})_{2}\{(1 M) \text {-biiq })\right]^{+}$and $(\Lambda)-\left[\mathrm{Ru}(\mathrm{acac})_{2}\{(1 P) \text {-biiq })\right]^{+}$cations. The ruthenium(II) analogue rac- $(\Delta)-\left[\mathrm{Ru}(\mathrm{acac})_{2}\{(1 P)\right.$-biiq $\left.\}\right]$ has also been structurally characterized (CSD Refcode OGIVUY, space group $P 2{ }_{1} / c, \mathrm{~N} 2-\mathrm{C} 1-\mathrm{C1}^{\prime}-\mathrm{N} 2^{\prime}$ torsion angle of $18.51^{\circ}$ ). Interestingly, in this case the lattice contains equal numbers of the two diastereoisomeric cations $(\Lambda)-\left[\mathrm{Ru}(\mathrm{acac})_{2}\{(1 M) \text {-biiq })\right]^{+}$and $(\Delta)-\left[\mathrm{Ru}(\mathrm{acac})_{2}\{(1 P) \text {-biiq })\right]^{+}$cations. It is unclear if the change in distereoisomeric selectivity in these two compounds is a case of diastereoisomerically selective crystallization for the two crystals determined, or if it reflects a more fundamental difference in thermodynamic stability of the complexes themselves. The $\mathrm{Ru}-\mathrm{O}$ and $\mathrm{Ru}-\mathrm{N}$ distances in the ruthenium(II) complex ( $\mathrm{Ru}-\mathrm{O}, 2.046-2.060 \AA, \mathrm{Ru}-\mathrm{N}, 1.991$, $1.993 \AA$ ) are significantly shorter than in the ruthenium(III) compound $(\mathrm{Ru}-\mathrm{O}, 2.010,2.011$ $\AA$, Ru-N, $2.037 \AA$ ) [140].

The complexes $\left[\mathrm{Ru}\left\{3,3^{\prime}-\left(\mathrm{O}_{2} \mathrm{C}-\mathrm{k} O\right)_{2}\right.\right.$ biiq- $\left.\left.\kappa^{2} N\right\} \mathrm{L}_{2}\right](\mathrm{L}=$ 4-methylpyridine, 6-bromoisoquinoline $)$ in which the $\left\{3,3^{\prime}-\left(\mathrm{O}_{2} \mathrm{C}\right)_{2} \mathrm{biiq}\right\}^{2-}$ ligand acts as a planar tetradentate $\mathrm{N}, \mathrm{N}^{\prime}, \mathrm{O}, \mathrm{O}^{\prime}-$ donor, have been prepared and shown to catalyze the oxidation of water in acidic media with $\mathrm{Ce}(\mathrm{IV})$ as the primary oxidant. Turnover numbers and frequencies are relatively modest, especially in comparison to related scaffolds based upon bpy or phen metal-binding domains [83]. The solid-state structure of $\left[\mathrm{Ru}\left\{3,3^{\prime}-\left(\mathrm{O}_{2} \mathrm{C}\right)_{2}\right.\right.$ biiq $\left.\} \mathrm{L}_{2}\right] \cdot 2 \mathrm{MeOH}$ ( $\mathrm{L}=6$-bromoisoquinoline) has been reported (CSD Refcode ABEVIP, space group $P \overline{1}$, Figure 12b) [83]. In the lattice there are equal numbers of complex molecules with (1M) and $(1 P)$ configurations of the biiq ligands, with an $\mathrm{N} 2-\mathrm{C} 1-\mathrm{C}^{\prime}-\mathrm{N} 2^{\prime}$ torsion angle of $-15.35^{\circ}$. In contrast, the complex $[\mathrm{Ru}($ biiq $) \mathrm{Cl}(\mathrm{tpy})]\left(\mathrm{PF}_{6}\right)_{2}$ showed no activity in water oxidation studies [141]. 


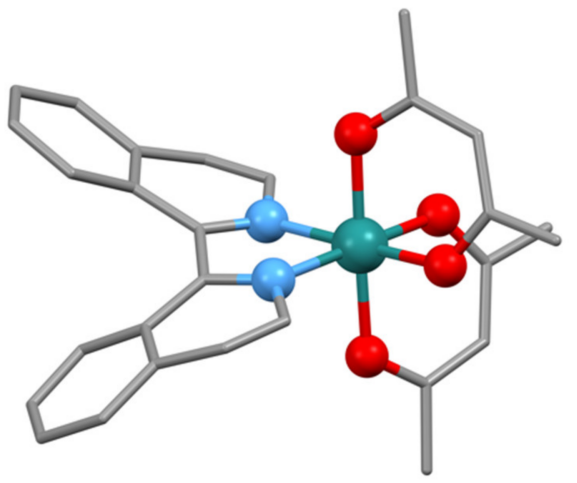

(a)

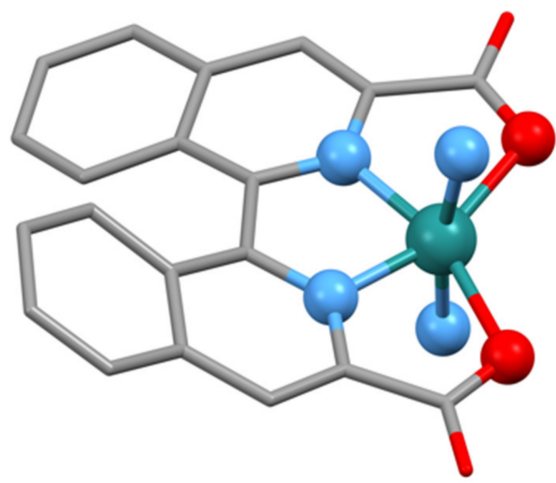

(b)

Figure 12. (a) The $(\Lambda)-\left[\mathrm{Ru}(\mathrm{acac})_{2}\{(1 P) \text {-biiq }\}\right]^{+}$cation present in $\mathrm{rac}-(\Delta)-\left[\mathrm{Ru}(\mathrm{acac})_{2}\{(1 M)\right.$-biiq $\left.\}\right]\left(\mathrm{ClO}_{4}\right)$. Equal numbers of $(\Delta)-\left[\operatorname{Ru}(\operatorname{acac})_{2}\{(1 M) \text {-biiq }\}\right]^{+}$cations are also present in the lattice. Hydrogen atoms omitted for clarity and donor atoms and the metal atoms are shown as balls; (b) The struc-

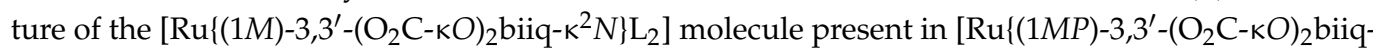
$\left.\left.\kappa^{2} N\right\} \mathrm{L}_{2}\right] \cdot 2 \mathrm{MeOH}\left(\mathrm{L}=6\right.$-bromoisoquinoline). Equal numbers of $\left[\mathrm{Ru}\left\{(1 P)-3,3^{\prime}-\left(\mathrm{O}_{2} \mathrm{C}-\kappa O\right){ }_{2}\right.\right.$ biiq- $\left.\left.\kappa^{2} N\right\} \mathrm{L}_{2}\right]$ molecules are present in the lattice. Hydrogen atoms omitted for clarity and donor atoms and the metal atoms are shown as balls. Only the nitrogen donor atoms of the 6-bromoisoquinoline ligands are shown.

\subsection{Group 9}

No cobalt complexes of biiq appear to have been isolated although electrospray MS studies of methanol solutions containing $\mathrm{CoCl}_{2}$ and biiq observed an ion assigned to the species $[\mathrm{Co}(\mathrm{biiq}) \mathrm{Cl}]^{+}[126]$

The reaction of $\left[(\operatorname{cod}) \mathrm{Rh}(\mu-\mathrm{Cl})_{2} \mathrm{Rh}(\operatorname{cod})\right]$ with $7,7^{\prime}-(\mathrm{MeO}){ }_{2}$ biiq gives $\left[\mathrm{Rh}(\operatorname{cod})\left\{7,7^{\prime}-\right.\right.$ $(\mathrm{MeO})_{2}$ biiq\}] $\left(\mathrm{ClO}_{4}\right)$ [114]. This observation was the basis for a study of the coordination of the related enantiopure macrocyclic ligands $(+)-7$ and $(1 M)-$ and $(1 P)-8$ with $\left[(\operatorname{cod}) \mathrm{Rh}(\mu-\mathrm{Cl})_{2} \mathrm{Rh}(\operatorname{cod})\right]$. The reaction of (+)-7 with $\left[(\operatorname{cod}) \mathrm{Rh}(\mu-\mathrm{Cl})_{2} \mathrm{Rh}(\operatorname{cod})\right]$ gave the structurally characterized complex $[\mathrm{Rh}\{(1 M P)-7\}(\mathrm{cod})]\left(\mathrm{ClO}_{4}\right) \cdot \mathrm{Me}_{2} \mathrm{CO}$ (CSD Refcode ZIJDIF, space group $P 2_{1} / a, \mathrm{~N} 2-\mathrm{C} 1-\mathrm{C} 1^{\prime}-\mathrm{N} 2^{\prime}$ torsion angle of $-28.49^{\circ}$, Figure $\left.13 a\right)$ in which the ligand has racemized and the lattice contains equal numbers of the $[\operatorname{Rh}\{(1 M)-7\}(\operatorname{cod})]^{+}$ and $[\operatorname{Rh}\{(1 P)-7\}(\operatorname{cod})]^{+}$cations. In contrast, the configurationally stable ligands $(1 M)-$ and $(1 P)-8$ give homochiral complexes with retention of configuration. The compound $[\mathrm{Rh}\{(1 \mathrm{M})-8\}(\mathrm{cod})]\left(\mathrm{ClO}_{4}\right) \cdot 2 \mathrm{CHCl}_{3}$ (CSD Refcode ZIJDOL, space group $\mathrm{P}_{1}{ }_{2} 2_{2} 2_{1}, \mathrm{~N} 2-\mathrm{C} 1-$ $\mathrm{C}^{\prime}-\mathrm{N} 2^{\prime}$ torsion angle of $-39.16^{\circ}$, Figure $13 \mathrm{~b}$ ) was structurally characterized, which also confirmed the $1 M$ configuration for the (-) enantiomer of the ligand. [53]

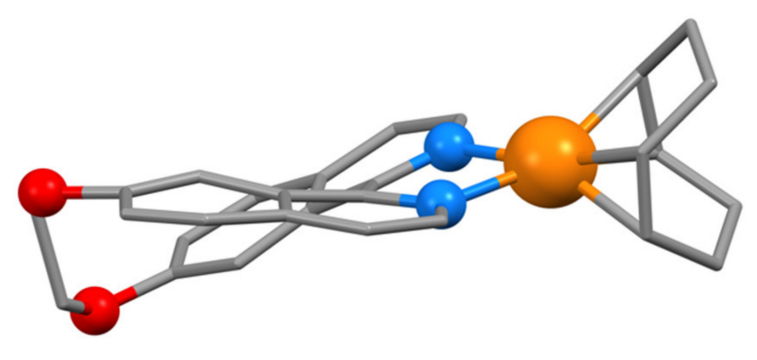

(a)

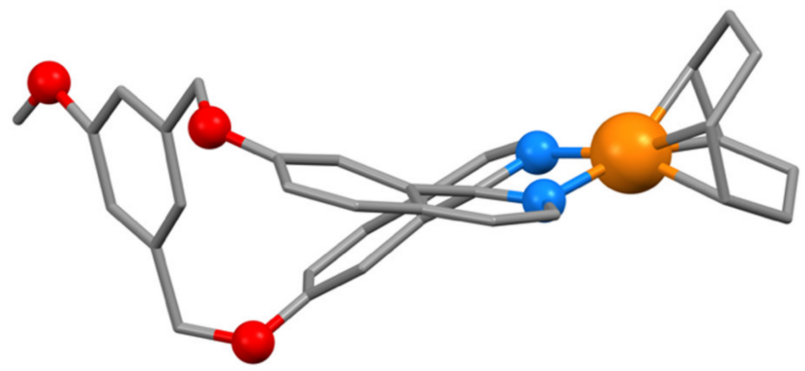

(b)

Figure 13. (a) The structure of the $[\operatorname{Rh}\{(1 M)-7\}(\operatorname{cod})]^{+}$cation found in $[\mathrm{Rh}\{(1 M P)-7\}(\operatorname{cod})]\left(\mathrm{ClO}_{4}\right) \cdot \mathrm{Me}_{2} \mathrm{CO}$ with hydrogen atoms omitted for clarity and non-carbon atoms as balls; (b) the structure of the $[\operatorname{Rh}\{(1 M)-8\}(\operatorname{cod})]^{+}$cation found in $[\mathrm{Rh}\{(1 \mathrm{M})-8\}(\mathrm{cod})]\left(\mathrm{ClO}_{4}\right) \cdot \mathrm{Me}_{2} \mathrm{CO}$ with hydrogen atoms omitted for clarity and non-carbon atoms as balls. 
Cationic iridium(III) complexes with cyclometalating ligands are of interest for application as emitters in organic light-emitting diodes (OLEDs) and light-emitting electrochemical cells (LECs). The complex $\left[\operatorname{Ir}(\mathbf{1 4})_{2}(\right.$ biiq $\left.)\right]\left(\mathrm{PF}_{6}\right)$ (Figure 14) has been prepared and the photophysical properties studied. The compound exhibits a strong orange-red emission at $672 \mathrm{~nm}[142]$. The related complex $\left[\operatorname{Ir}(\mathbf{1 5})_{2}(\right.$ biiq $\left.)\right]\left(\mathrm{PF}_{6}\right)($ Figure 14) has been prepared and the photophysical properties as well as the solid-state structure reported (CSD Refcode REMQOQ, space group $P \overline{1}, \mathrm{~N} 2-\mathrm{C} 1-C 1^{\prime}-\mathrm{N} 2^{\prime}$ torsion angle $-30.36^{\circ}$, Figure 14) [91]. In the solid-state structure of rac- $(\Delta)-\left[\operatorname{Ir}(\mathbf{1 5})_{2}\{(1 M)\right.$-biiq $\left.)\right]\left(\mathrm{PF}_{6}\right)$, there are equal numbers of $(\Lambda)-\left[\operatorname{Ir}(15)_{2}\{(1 M)-\text { biiq }\}\right]^{+}$and $(\Delta)-\left[\operatorname{Ir}(15)_{2}\{(1 P) \text {-biiq }\}\right]^{+}$cations.
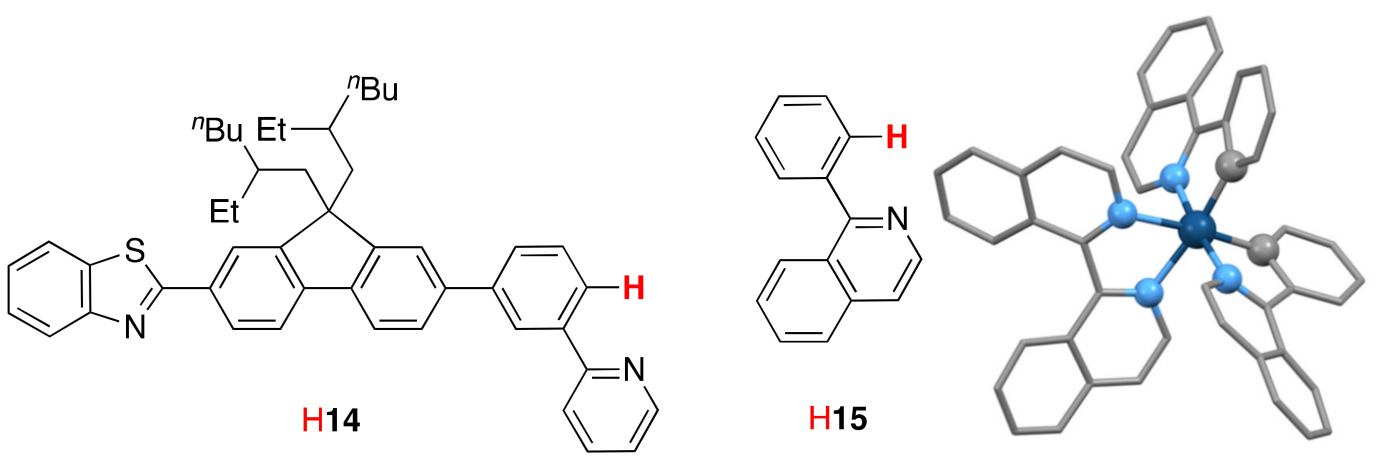

Figure 14. Two cyclometalating ligands $\left(\mathrm{HC}^{\wedge} \mathrm{N}\right)$ which form strongly luminescent iridium(III) complexes of the type $\left[\operatorname{Ir}(\mathrm{biiq})\left(\mathrm{C}^{\wedge} \mathrm{N}\right)_{2}\right]\left(\mathrm{PF}_{6}\right)$ and the solid-state structure of the $(\Lambda)-\left[\operatorname{Ir}(\mathbf{1 5})_{2}\{(1 M) \text {-biiq }\}\right]^{+}$ cation present in rac- $(\Delta)\left[\operatorname{Ir}(\mathbf{1 5})_{2}\{(1 M)\right.$-biiq $\left.)\right]\left(\mathrm{PF}_{6}\right)$. Hydrogen atoms have been omitted for clarity and donor atoms are represented as balls.

\subsection{Group 10}

The bright green paramagnetic complex $\left[\mathrm{Ni}(\mathrm{biiq})_{3}\right]^{2+}$ has been isolated from the reaction of biiq with $\left[\mathrm{Ni}\left(\mathrm{H}_{2} \mathrm{O}\right)_{6}\right]\left(\mathrm{ClO}_{4}\right)_{2}$ in $\mathrm{EtOH}$ [77]. In contrast, the reaction with $\mathrm{NiCl}_{2} \cdot 6 \mathrm{H}_{2} \mathrm{O}$ in ${ }^{n} \mathrm{BuOH}$ gives the structurally characterized compound [Ni(biiq) ${ }_{2} \mathrm{Cl}_{2}$ ] (CSD Refcode BAFRUY, space group $P 21_{1} / c, \mathrm{~N} 2-\mathrm{C} 1-\mathrm{C} 1^{\prime}-\mathrm{N} 2^{\prime}$ torsion angles $-40.11,36.91^{\circ}$, Figure $15 \mathrm{a}$ ) which has been shown to be an effective catalyst for the Suzuki coupling reaction [143]. Each molecule contains one biiq ligand with the $1 M$ configuration and one with the $1 P$ configuration leading to the full description cis-rac- $(\Delta)-[\mathrm{Ni}\{\{1 M)$-biiq $\}(1 P)$-biiq $\left.\} \mathrm{Cl}_{2}\right]$ (remember that the metal is also a stereogenic center in an octahedral $\left\{\mathrm{M}\left(\mathrm{N}^{\wedge} \mathrm{N}\right)_{2} \times{ }_{2}\right\}$ species, where $\mathrm{N}^{\wedge} \mathrm{N}$ is a chelating bidentate ligand). The complex $\left[\mathrm{Pd}(\mathrm{biiq}) \mathrm{Cl}_{2}\right]$ has also been prepared and structurally characterized (CSD Refcode BAFSUZ, space group $P 2_{1} / c, \mathrm{~N} 2-\mathrm{C} 1-\mathrm{C}^{\prime}-\mathrm{N} 2^{\prime}$ torsion angles $-22.48,27.64^{\circ}$, Figure $15 b$ ) and is effective as a catalyst in Suzuki and Heck reactions as well as in hydroxylation reactions [143]. The lattice of $\left[\mathrm{Pd}(\mathrm{biiq}) \mathrm{Cl}_{2}\right]$ contains equal numbers of crystallographically independent $\left[\mathrm{Pd}[(1 M)\right.$-biiq $\left.\} \mathrm{Cl}_{2}\right]$ and $\left[\mathrm{Pd}\{(1 P)\right.$-biiq $\left.\} \mathrm{Cl}_{2}\right]$ molecules.

The reaction of biiq with the chiral complexes $\left[\{(R)-\mathbf{1 6}-\kappa C N\} \operatorname{Pd}(\mu-C l)_{2} \operatorname{Pd}\{(R)-\mathbf{1 6}-\kappa C N\}\right]$ or $\left[\{(S)-16-\kappa C N\} \operatorname{Pd}(\mu-C l)_{2} \operatorname{Pd}\{(S)-16-\kappa C N\}\right]$ is diastereoisomer specific and gives the structurally characterized complexes $\left[\{(R)-\mathbf{1 6}-\kappa C N\} \operatorname{Pd}(\mu-\mathrm{Cl})\left(\mu-(1 M)\right.\right.$-biiq- $\left.1 \kappa N, 2 \kappa N^{\prime}\right) \operatorname{Pd}\{(R)-\mathbf{1 6}$ $\kappa \mathrm{CN}\}]\left(\mathrm{ClO}_{4}\right)\left(\mathrm{CSD}\right.$ Refcode FOSVOY, space group $P 2_{1} 2_{1} 2_{1}, \mathrm{~N} 2-\mathrm{C} 1-\mathrm{C}^{\prime}-\mathrm{N} 2^{\prime}$ torsion angles $\left.-93.72^{\circ}\right)$ and $\left[\{(S)-16-\kappa C N\} \operatorname{Pd}(\mu-\mathrm{Cl})\left(\mu-(1 P)-\right.\right.$ biiq- $\left.\left.1 \kappa N, 2 \kappa N^{\prime}\right) \operatorname{Pd}\{(S)-16-\kappa C N\}\right]\left(\mathrm{ClO}_{4}\right)(\mathrm{CSD}$ Refcode FOSVUE, space group $P 2{ }_{1} 2_{1} 2_{1}, \mathrm{~N} 2-\mathrm{C} 1-\mathrm{C}^{\prime}-\mathrm{N} 2^{\prime}$ torsion angle $91.59^{\circ}$ ) each containing a bridging biiq ligand (Scheme 5) [44]. The same strategy for the resolution of $8,8^{\prime}-\mathrm{Me}_{2}$ biiq was less successful giving mixtures of diastereoisomers. However, using the corresponding reactions using H17 exhibited a high diastereoselectivity and optically pure $(1 P)-8,8^{\prime}-\mathrm{Me}_{2}$ biiq and $(1 M)-8,8^{\prime}-\mathrm{Me}_{2}$ biiq were isolated from mother liquors or by

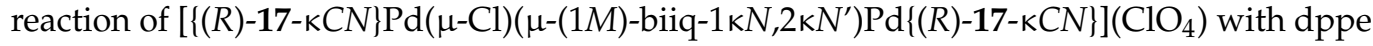
(1,2-bis(diphenylphosphano)ethane), respectively [43]. 


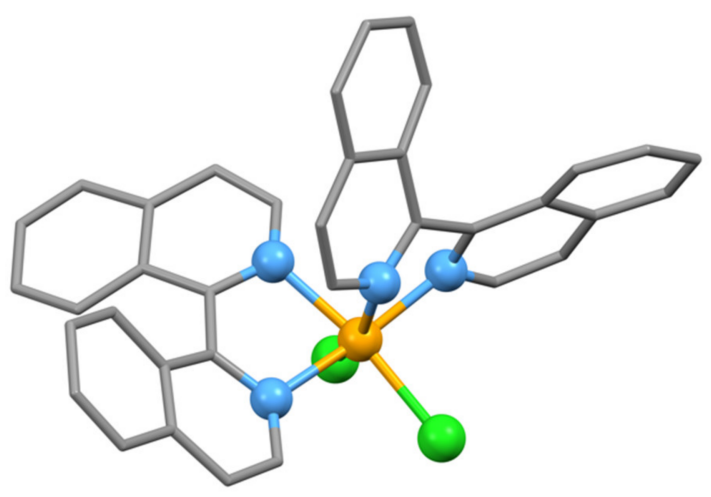

(a)

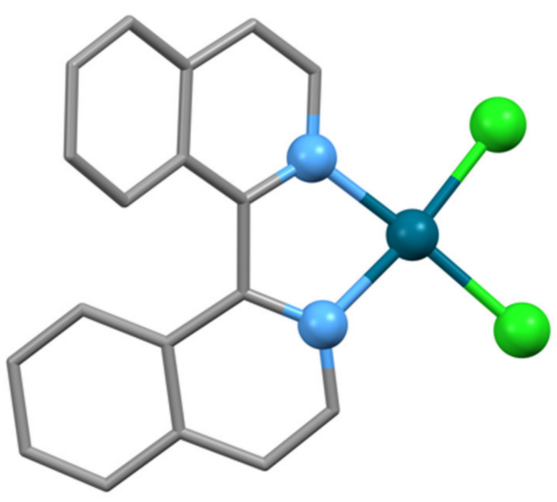

(b)

Figure 15. (a) A molecule of the complex cis- $(\Delta)-\left[\mathrm{Ni}\{\{M)\right.$-biiq $\}\{(P)$-biiq $\left.\} \mathrm{Cl}_{2}\right]$ present in cis-rac- $(\Delta)$ $\left[\mathrm{Ni}\{\{1 M)\right.$-biiq $\}\{(1 P)$-biiq $\left.\} \mathrm{Cl}_{2}\right]$; equal numbers of cis- $(\Lambda)$-[Ni $\{\{1 M)$-biiq $\}\{(1 P)$-biiq $\left.\} \mathrm{Cl}_{2}\right]$ molecules are present in the lattice. The donor atoms and nickel are shown as balls, and hydrogen atoms are omitted for clarity; (b) one of the two independent molecules of $\left[\mathrm{Pd}(\right.$ biiq $\left.) \mathrm{Cl}_{2}\right]$ present in cis-rac-[Pd$\{(1 M)$ biiq $\left.\} \mathrm{Cl}_{2}\right]$. The molecule represented is cis-[Pd$\{(1 P)$-biiq $\left.\} \mathrm{Cl}_{2}\right]$. The other independent molecule possesses the $M$ configuration. The donor atoms and palladium are shown as balls and hydrogen atoms omitted for clarity.

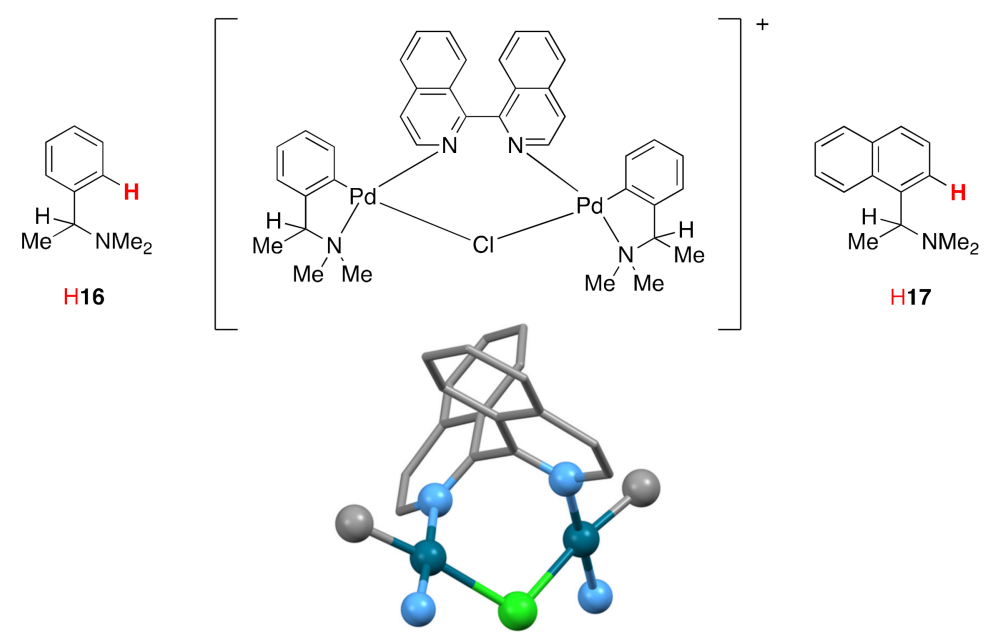

Scheme 5. The chiral complexes $\left[\{(R)-16-\kappa C N\} \operatorname{Pd}(\mu-C l)_{2} \operatorname{Pd}\{(R)-16-\kappa C N\}\right]$ or $[\{(S)-16-\kappa C N\} \operatorname{Pd}(\mu-$ $\left.\mathrm{Cl})_{2} \operatorname{Pd}\{(S)-16-\kappa C N\}\right]$ can be used to form the complexes $[\{(R)-16-\kappa C N\} \operatorname{Pd}(\mu-C l)(\mu-(1 M)-$

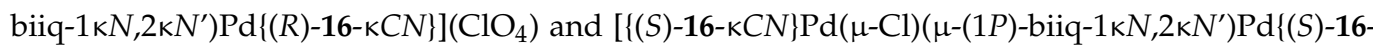
$\kappa C N\}]\left(\mathrm{ClO}_{4}\right)$ diastereoselectively. The solid-state structure of the $[\{(S)-16-\kappa C N\} \mathrm{Pd}(\mu-\mathrm{Cl})(\mu-(1 P)-$

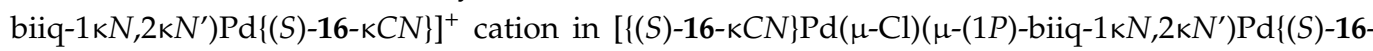
$\kappa C N\}]\left(\mathrm{ClO}_{4}\right)$ is shown. Only the $\mathrm{C}$ and $\mathrm{N}$ donor atoms of the cyclometalated 16 ligands are shown. Hydrogen atoms have been omitted for clarity and donor atoms and the metal centers are depicted as balls.

Electrospray and collision-induced dissociation MS studies of methanol solutions containing group 10 compounds and biiq have been reported [126]. The catalytic system $\left[\mathrm{Pd}\left(\mathrm{O}_{2} \mathrm{CCF}_{3}\right)_{2}\right]$-biiq has been shown experimentally to be moderately active in the reaction of 2,6-dimethoxybenzoic acid with $\mathrm{MeCN}$ to give 2,6-dimethoxyacetophenone; investigations at the DFT level were also reported [144].

The orange complex [ $\mathrm{Pt}$ (biiq) $\mathrm{Cl}_{2}$ ] has been prepared by the direct reaction of $\mathrm{K}_{2}\left[\mathrm{PtCl}_{4}\right]$ with biiq in water; the complex has been structurally characterized (CSD Refcode LEKXOO, space group $P 2{ }_{1} / c$ ) and closely resembles the palladium analog (see above), with the lattice containing equal numbers of crystallographically independent $\left[\mathrm{Pt}\left[(1 \mathrm{M})\right.\right.$-biiq $\left.\mathrm{Cl}_{2}\right]$ 
and $\left[\operatorname{Pt}\{(1 P)\right.$-biiq $\left.\} \mathrm{Cl}_{2}\right]$ molecules with different torsion angles $\left(35.18\right.$ and $\left.41.12^{\circ}\right)$ [145]. The reaction of $\left[\mathrm{Pt}(\mathrm{biiq}) \mathrm{Cl}_{2}\right]$ with pyridine or $4-\left(\mathrm{N}, \mathrm{N}^{\prime}\right.$-dimethylamino)pyridine $\left(4-\mathrm{Me}_{2} \mathrm{Npy}\right)$ gives the complexes $\left[\mathrm{Pt}(\right.$ biiq $\left.-\kappa N)(\mathrm{py})_{3}\right]$ and $\left[\mathrm{Pt}(\right.$ biiq $\left.-\kappa N)\left(4-\mathrm{Me}_{2} \mathrm{Npy}\right)_{3}\right]$, respectively, each containing a monodentate biiq ligand. In the structurally characterized compound [Pt(biiq$\kappa N)\left(4-\mathrm{Me}_{2} \mathrm{Npy}_{3}\right.$ ] (CSD Refcode LEKXUU, space group $\left.P \overline{1}\right)$ the torsion angle between the two isoquinoline ring systems of the biiq is $77.61^{\circ}$ [145].

\subsection{Group 11}

Until recently, the only biiq complex containing copper (outside the patent literature) was the red copper(I) compound $\left[\mathrm{Cu}(\text { biiq })_{2}\right]\left(\mathrm{ClO}_{4}\right)$ obtained from the reaction of biiq with $\left[\mathrm{Cu}\left(\mathrm{CH}_{3} \mathrm{CN}\right)_{4}\right]\left(\mathrm{ClO}_{4}\right)$ in $\mathrm{MeCN}$ [146]. The compound is relatively air-sensitive. We recently reported the preparation, characterization and photophysical properties of $[\mathrm{Cu}(\mathrm{POP})(\mathrm{biiq})]\left(\mathrm{PF}_{6}\right)$ and $[\mathrm{Cu}($ xantphos $)($ biiq $)]\left(\mathrm{PF}_{6}\right)(\mathrm{POP}=\mathrm{bis}(2-($ diphenylphosphanyl)phenyl)ether, xantphos $=(9,9$-dimethyl-9H-xanthene-4,5-diyl)bis(diphenylphosphane) with a view to incorporating them as electroluminescent layers in light-emitting electrochemical cells. The NMR spectra indicate several concurrent dynamic processes involving inversion of both coordinated ligands. The solid-state structure of $[\mathrm{Cu}(\mathrm{POP})\{(1 M P)-$ biiq $\}]\left(\mathrm{PF}_{6}\right)$ has been determined (space group $P \overline{1}, \mathrm{~N} 2-\mathrm{C} 1-\mathrm{C} 1^{\prime}-\mathrm{N} 2{ }^{\prime}$ torsion angle -38.46 ) (Figure 16) [147].

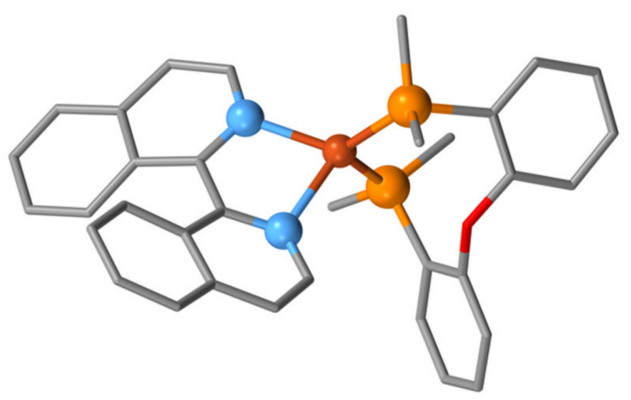

Figure 16. One of the enantiomeric $[\mathrm{Cu}(\mathrm{POP})\{(1 M)-\mathrm{biiq}\}]^{+}$cations present in $[\mathrm{Cu}(\mathrm{POP})\{(1 M P)$ biiq\}] $\left(\mathrm{PF}_{6}\right)$ The donor atoms and copper are shown as balls and hydrogen atoms omitted for clarity with only the ipso carbon atoms of the $\mathrm{Ph}_{2} \mathrm{P}$ groups shown.

Electrospray and collision-induced dissociation MS studies of methanol solutions containing $\mathrm{CuCl}_{2}$ and biiq exhibited ions assigned to the species $\left[\mathrm{Cu}(\text { biiq })_{2} \mathrm{Cl}\right]^{+},\left[\mathrm{Cu}(\text { biiq) } \mathrm{Cl}]^{+}\right.$ and $\left[\mathrm{Cu}_{2}(\text { biiq })_{2}(\mathrm{Cl})_{3}\right]^{+}[126]$. In an extension to this work, heteroleptic and homoleptic complexes incorporating biiq and functionalized derivatives, bpy and phen were studied using ESMS and in situ complexation. Collision-induced decomposition measurements were used to determine the relatives tabilities of the copper(II) complexes [84].

As always, silver(I) complexes can be relied upon to provide new delights of structural diversity. Structurally characterized complexes containing silver(I) all contain two-, threeor four-coordinate silver(I) centers; no example of a chelating bidentate biiq ligand has been structurally characterized. Several structural motifs with biiq-Ag stoichiometries of 2:1, 1:2 and 1:1 have been reported. The compounds $\left[\left\{\mathrm{Ag}(\mu \text {-biiq })_{2}\right\}_{n}\right] \mathrm{X}_{2}\left(\mathrm{X}=\mathrm{BF}_{4}\right.$ or $\left.\mathrm{CF}_{3} \mathrm{SO}_{3}\right)$ of 2:1 stoichiometry are thought on the basis of conductivity data to be oligomeric or polymeric species containing silver centers coordinated to four biiq nitrogen donors [148]. The compounds of 2:2 stoichiometry $\left[\left(\mathrm{Ph}_{3} \mathrm{P}\right) \mathrm{Ag}\left(\mu \text {-biiq- } 1 \kappa N, 2 \kappa N^{\prime}\right)_{2} \mathrm{Ag}\left(\mathrm{PPh}_{3}\right)\right]\left(\mathrm{ClO}_{4}\right)_{2} \cdot 3 \mathrm{Me}_{2} \mathrm{CO}$ (CSD Refcode YAQSIU, space group $P \overline{1}, \mathrm{~N} 2-\mathrm{C} 1-\mathrm{C}^{\prime}-\mathrm{N} 2^{\prime}$, two crystallographically independent cations with torsion angles $-100.28,100.28^{\circ}$ and $94.53,-94.53^{\circ}$, Figure 17a),

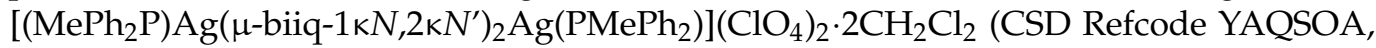
space group $P \overline{1}, \mathrm{~N} 2-\mathrm{C} 1-\mathrm{C} 1^{\prime}-\mathrm{N} 2^{\prime}$ torsion angle $\left.-79.73,79.73^{\circ}\right)$ and $\left[\left(\mathrm{MePh}_{2} \mathrm{P}\right) \mathrm{Ag}(\mu-\mathrm{biiq}-\right.$ $\left.\left.1 \kappa N, 2 \kappa N^{\prime}\right)_{2} \mathrm{Ag}\left(\mathrm{PMePh}_{2}\right)\right]\left(\mathrm{CF}_{3} \mathrm{SO}_{3}\right)_{2} \cdot 2 \mathrm{CH}_{2} \mathrm{Cl}_{2}$ (CSD Refcode YAQSUG, space group $P 2{ }_{1} / c$, $\mathrm{N} 2-\mathrm{C} 1-\mathrm{C} 1^{\prime}-\mathrm{N} 2^{\prime}$ torsion angles $-98.03,98.03^{\circ}$ ) all contain discrete, centrosymmetric dinuclear cations with two three-coordinate silver centers [148]. A similar dinuclear $\{\mathrm{Ag}(\mu$-biiq$\left.\left.1 \kappa N, 2 \kappa N^{\prime}\right)_{2} \mathrm{Ag}\right\}$ core is present in $\left[\mathrm{Ag}_{2}\left(\mu \text {-biiq- } 1 \kappa N, 2 \kappa N^{\prime}\right)_{2}\right]\left(\mathrm{CF}_{3} \mathrm{SO}_{3}\right)_{2} \cdot 4 \mathrm{Me}_{2} \mathrm{CO}$ which exhibits 
many short Ag ... O contacts (CSD Refcode YAQRUF, space group C2/c, N2-C1-C1'-N2' torsion angles $\left.67.84,66.00^{\circ}\right)$ and $\left[\left(\mathrm{CF}_{3} \mathrm{SO}_{3}-\kappa \mathrm{O}\right) \mathrm{Ag}(\mu \text {-biiq })_{2} \mathrm{Ag}\left(\mathrm{CF}_{3} \mathrm{SO}_{3}-\kappa O\right)\right] \cdot 2 \mathrm{Me}_{2} \mathrm{CO}(\mathrm{CSD}$ Refcode YAQSAM, space group Pbcn, N2-C1-C1'-N2' torsion angles 68.22, 79.95 ${ }^{\circ}$ [148]. In $\left[\mathrm{Ag}_{2}\left\{\left(\mu \text {-biiq- } 1 \kappa N, 2 \kappa N^{\prime}\right)_{2}\right]\left(\mathrm{CF}_{3} \mathrm{SO}_{3}\right)_{2} \cdot 4 \mathrm{Me}_{2} \mathrm{CO}\right.$ and $\left[\left(\mathrm{CF}_{3} \mathrm{SO}_{3}-\kappa O\right) \mathrm{Ag}(\mu \text {-biiq })_{2} \mathrm{Ag}\left(\mathrm{CF}_{3} \mathrm{SO}_{3}-\right.\right.$ $\kappa \mathrm{O})] \cdot 2 \mathrm{Me}_{2} \mathrm{CO}$, equal numbers of the homochiral cations $\left[\mathrm{Ag}_{2}\left\{(1 P)-\mu \text {-biiq- } 1 \kappa N, 2 \kappa N^{\prime}\right\}_{2}\right]^{2+}$ and

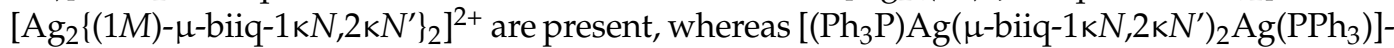
$\left(\mathrm{ClO}_{4}\right)_{2} \cdot 3 \mathrm{Me}_{2} \mathrm{CO},\left[\left(\mathrm{MePh}_{2} \mathrm{P}\right) \mathrm{Ag}\left(\mu \text {-biiq- } 1 \kappa N, 2 \kappa N^{\prime}\right)_{2} \mathrm{Ag}\left(\mathrm{PMePh}_{2}\right)\right]\left(\mathrm{ClO}_{4}\right)_{2} \cdot 2 \mathrm{CH}_{2} \mathrm{Cl}_{2}$ and $[(\mathrm{Me}-$ $\left.\left.\mathrm{Ph}_{2} \mathrm{P}\right) \mathrm{Ag}\left(\mu \text {-biiq- } 1 \kappa N, 2 \kappa N^{\prime}\right)_{2} \mathrm{Ag}\left(\mathrm{PMePh}_{2}\right)\right]\left(\mathrm{CF}_{3} \mathrm{SO}_{3}\right)_{2} \cdot 2 \mathrm{CH}_{2} \mathrm{Cl}_{2}$ contain heterochiral $[\mathrm{Ag} 2\{(1 M)-$

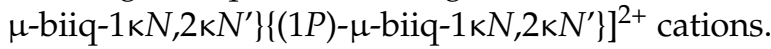

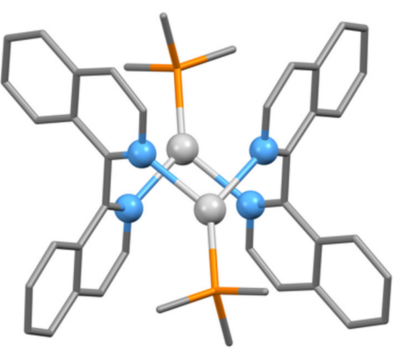

(a)

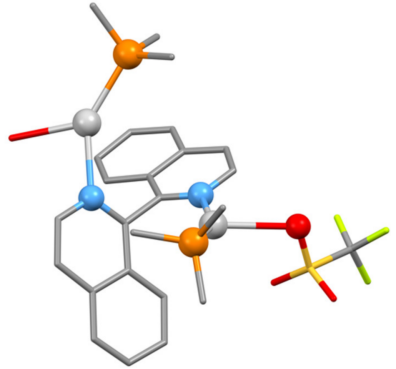

(b)

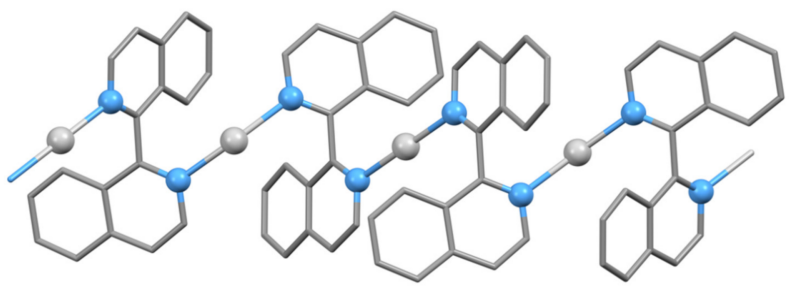

(c)

Figure 17. (a) The $\left[\left(\mathrm{Ph}_{3} \mathrm{P}\right) \mathrm{Ag}(\mu \text {-biiq })_{2} \mathrm{Ag}\left(\mathrm{PPh}_{3}\right)\right]^{2+}$ cation present in $\left[\left(\mathrm{Ph}_{3} \mathrm{P}\right) \mathrm{Ag}(\mu \text {-biiq })_{2} \mathrm{Ag}\left(\mathrm{PPh}_{3}\right)\right]$ $\left(\mathrm{ClO}_{4}\right)_{2} \cdot 3 \mathrm{Me}_{2} \mathrm{CO}$ with donor atoms and silver atoms shown as balls, only the ipso carbon atoms of the $\mathrm{Ph}_{3} \mathrm{P}$ ligands are shown, and hydrogen atoms are omitted for clarity; (b) the compound $\left[\left(\mathrm{CF}_{3} \mathrm{SO}_{3}\right)\left(\mathrm{Ph}_{3} \mathrm{P}\right) \mathrm{Ag}(\mu \text {-biiq })_{2} \mathrm{Ag}\left(\mathrm{OH}_{2}\right)\left(\mathrm{PPh}_{3}\right)\right]^{+}$cation present in $\left[\left(\mathrm{CF}_{3} \mathrm{SO}_{3}\right)\left(\mathrm{Ph}_{3} \mathrm{P}\right) \mathrm{Ag}(\mu-\right.$ biiq) $\left.{ }_{2} \mathrm{Ag}\left(\mathrm{OH}_{2}\right)\left(\mathrm{PPh}_{3}\right)\right]\left(\mathrm{CF}_{3} \mathrm{SO}_{3}\right) \cdot \mathrm{CHCl}_{3}$ with donor atoms and silver atoms shown as balls, only the ipso carbon atoms of the $\mathrm{Ph}_{3} \mathrm{P}$ ligands shown and hydrogen atoms omitted for clarity; (c) the one-dimensional $\left[\{\mathrm{Ag}(\mu \text {-biiq })\}_{n}\right]^{n+}$ cation in $\left[\{\mathrm{Ag}(\mu \text {-biiq })\}_{n}\right]\left(\mathrm{CF}_{3} \mathrm{SO}_{3}\right)_{n} \cdot n \mathrm{H}_{2} \mathrm{O}$ with donor atoms and silver atoms shown as balls and hydrogen atoms omitted for clarity.

A 1:2 stoichiometry is found in the compound $\left[\left(\mathrm{CF}_{3} \mathrm{SO}_{3}\right)\left(\mathrm{Ph}_{3} \mathrm{P}\right) \mathrm{Ag}\left(\mu \text {-biiq- } 1 \kappa N, 2 \kappa N^{\prime}\right)_{2-}\right.$ $\left.\mathrm{Ag}\left(\mathrm{OH}_{2}\right)\left(\mathrm{PPh}_{3}\right)\right]\left(\mathrm{CF}_{3} \mathrm{SO}_{3}\right) \cdot \mathrm{CHCl}_{3}\left(\mathrm{CSD}\right.$ Refcode $\mathrm{YAQROZ}$, space group $P \overline{1}, \mathrm{~N} 2-\mathrm{C} 1-\mathrm{C} 1^{\prime}-\mathrm{N} 2^{\prime}$ torsion angle $113.05^{\circ}$, Figure $17 \mathrm{~b}$ ) and related species with other phosphane ligands and anions [148]. The complexes $\left[\{\mathrm{Ag}(\mu \text {-biiq })\}_{n}\right] \mathrm{X}\left(\mathrm{X}=\mathrm{BF}_{4}\right.$ or $\left.\mathrm{CF}_{3} \mathrm{SO}_{3}\right) \cdot \mathrm{H}_{2} \mathrm{O}$ are one-dimensional polymers; the solid-state structure of $\left[\left\{\mathrm{Ag}\left(\mu \text {-biiq- } 1 \kappa N, 2 \kappa N^{\prime}\right)\right\}_{n}\right]\left(\mathrm{CF}_{3} \mathrm{SO}_{3}\right)_{n} \cdot n \mathrm{H}_{2} \mathrm{O}(\mathrm{CSD}$ Refcode YAQSEQ, space group $\mathrm{C} 2 / c, \mathrm{~N} 2-\mathrm{C} 1-\mathrm{C} 1^{\prime}-\mathrm{N} 2^{\prime}$ torsion angle $111.76^{\circ}$, Figure $17 \mathrm{c}$ ) has been reported [148].

Electrospray MS studies of methanol solutions containing $\mathrm{Ag}\left(\mathrm{BF}_{4}\right)$ and biiq exhibited ions assigned to the species $\left[\mathrm{Ag}(\mathrm{biiq})_{2}\right]^{+}$and $[\mathrm{Ag}(\mathrm{biiq})]^{+}$; if bpy (1) or phen (2) were also in the solution the ions $[\mathrm{Ag}(\mathrm{biiq})(\mathbf{1})]^{+}$and $[\mathrm{Ag}(\mathrm{biiq})(\mathbf{2})]^{+}$were observed [126]. Subsequent studies together with DFT level calculations were reported for substituted biiq ligands [85].

The preferred geometry for gold(I) is linear two-coordinate and the biiq ligand cannot, therefore, coordinate in a chelating bidentate mode. Two types of discrete complexes are found with gold(I) centers. A monodentate biiq ligand is found in [Au(biiq- $k N)\left(\mathrm{C}_{6} \mathrm{~F}_{5}\right)$ ] and also in the structurally characterized compound $\left[\mathrm{Au}(\right.$ biiq- $\left.\mathrm{kN})\left(\mathrm{PPh}_{3}\right)\right]\left(\mathrm{CF}_{3} \mathrm{SO}_{3}\right)(\mathrm{CSD}$ Refcode DEGMUZ, space group $P \overline{1}, \angle \mathrm{P}-\mathrm{Au}-\mathrm{N}, 175.84^{\circ}$, N2-C1-C1'-N2' torsion angle $-100.32^{\circ}$, Figure 18a) [149]. In contrast, bridging biiq ligands are found in the com- 
pounds $\left[\left(\mathrm{Me}_{3} \mathrm{P}\right) \mathrm{Au}\left(\right.\right.$ biiq $\left.\left.-1 \kappa N, 2 \kappa N^{\prime}\right) \mathrm{Au}\left(\mathrm{PMe}_{3}\right)\right]\left(\mathrm{CF}_{3} \mathrm{SO}_{3}\right)_{2}(\mathrm{CSD}$ Refcode DEGMIN, space group $\mathrm{Pca}_{1}, \angle \mathrm{P}-\mathrm{Au}-\mathrm{N}, 175.29,176.24^{\circ}, \mathrm{N} 2-\mathrm{C} 1-\mathrm{C} 1^{\prime}-\mathrm{N} 2^{\prime}$ torsion angle $65.17^{\circ}$, Figure $18 \mathrm{~b}$ ), $\left[\left(\mathrm{MePh}_{2} \mathrm{P}\right) \mathrm{Au}\left(\right.\right.$ biiq- $\left.\left.1 \kappa N, 2 \kappa N^{\prime}\right) \mathrm{Au}\left(\mathrm{PMePh}_{2}\right)\right]\left(\mathrm{CF}_{3} \mathrm{SO}_{3}\right)_{2}(\mathrm{CSD}$ Refcode DEGMOT, space group $P \overline{1}, \angle \mathrm{P}-\mathrm{Au}-\mathrm{N}, 175.63,176.89^{\circ}, \mathrm{N} 2-\mathrm{C} 1-\mathrm{C}^{\prime}-\mathrm{N} 2^{\prime}$ torsion angle $\left.95.67^{\circ}\right)$ and $\left[\left(\mathrm{C}_{6} \mathrm{~F}_{5}\right) \mathrm{Au}(\right.$ biiq$\left.\left.1 \kappa N, 2 \kappa N^{\prime}\right) \mathrm{Au}\left(\mathrm{C}_{6} \mathrm{~F}_{5}\right)\right]\left(\mathrm{CSD}\right.$ Refcode DEGNAG, space group $\mathrm{C} 2 / \mathrm{c}, \angle \mathrm{C}-\mathrm{Au}-\mathrm{N} 178.96^{\circ}, \mathrm{N} 2-$ $\mathrm{C} 1-\mathrm{C}^{\prime}-\mathrm{N} 2^{\prime}$ torsion angle $80.10^{\circ}$ ) [149].

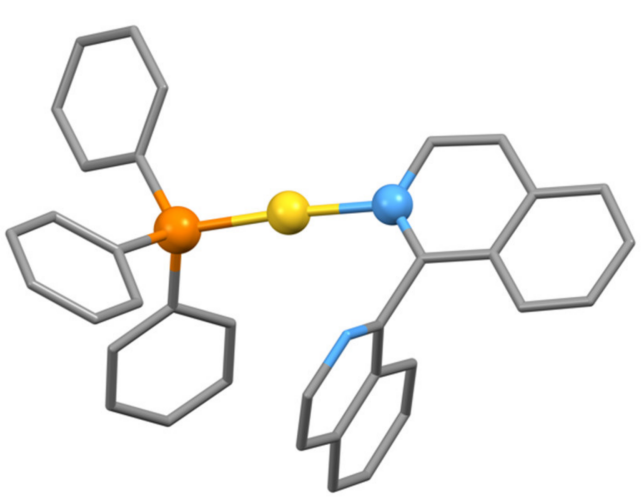

(a)

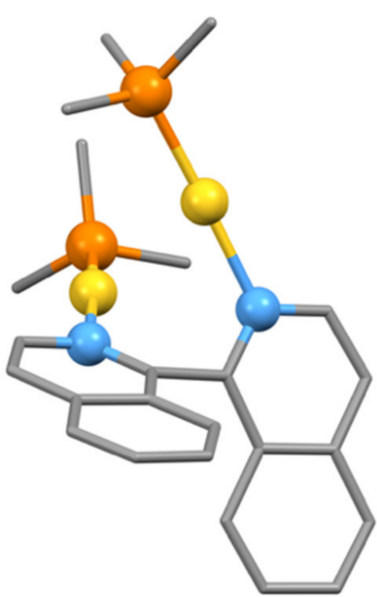

(b)

Figure 18. (a) In the compound $\left[\mathrm{Au}(\right.$ biiq- $\left.\mathrm{k} N)\left(\mathrm{PPh}_{3}\right)\right]\left(\mathrm{CF}_{3} \mathrm{SO}_{3}\right)$ the biiq ligand is monodentate and coordinates to a single near-linear $\left(\angle \mathrm{P}-\mathrm{Au}-\mathrm{N}, 175.84^{\circ}\right)$, two coordinate gold center with the donor atoms and the gold atoms represented as balls and hydrogen atoms omitted for clarity; (b) whereas a bridging mode is found in $\left[\left(\mathrm{Me}_{3} \mathrm{P}\right) \mathrm{Au}\left(\right.\right.$ biiq $\left.\left.-1 \kappa N, 2 \kappa N^{\prime}\right) \mathrm{Au}\left(\mathrm{PMe}_{3}\right)\right]\left(\mathrm{CF}_{3} \mathrm{SO}_{3}\right)_{2}$ with the donor atoms and the gold atoms represented as balls and hydrogen atoms omitted for clarity.

\subsection{Group 12}

Electrospray MS studies of methanol solutions containing $\mathrm{Zn}(\mathrm{OAc})_{2}$ and biiq exhibited ions assigned to the species $\left[\mathrm{Zn}(\mathrm{biiq})_{2}(\mathrm{OAc})\right]^{+}$and $[\mathrm{Zn}(\mathrm{biiq})(\mathrm{OAc})]^{+}$. In contrast, similar studies using $\mathrm{Cd}\left(\mathrm{NO}_{3}\right)_{2}$ gave species assigned to $\left[\mathrm{Cd}(\mathrm{biiq})\left(\mathrm{OCH}_{3}\right)_{2}\right]^{+}$. The formula reported for $[\mathrm{Zn}(\text { biiq })(\mathrm{OAc})]^{+}$and the masses for $[\mathrm{Zn}(\text { biiq })(\mathrm{OAc})]^{+}$and $\left[\mathrm{Cd}(\mathrm{biiq})\left(\mathrm{OCH}_{3}\right)_{2}\right]^{+}$are incorrect and these formulations must be regarded as suspect [126].

\section{Conclusions}

This review has attempted to present a comprehensive discussion of the chemistry, particularly the coordination chemistry of 1,1'-biisoquinoline. The consequences of coordination of these atropisomeric ligands identified the need for a refinement and clarification of the stereochemical nomenclature for complexes with multiple stereogenic sites and we offer a first approach.

Author Contributions: All authors contributed to the conceptualization and writing of this article and agreed to the published version of the manuscript.

Funding: This research received no external funding.

Acknowledgments: We would like to thank Michael Ashby for additional information regarding the spontaneous resolution of $[\mathrm{Os}\{(1 \mathrm{M})$-biiq $\} \mathrm{Cl}(\mathrm{tpy})] \mathrm{Cl} \cdot \mathrm{H}_{2} \mathrm{O}$. ECC and $\mathrm{RH}$ would like to thank their friends and colleagues in IUPAC Division VIII for an ongoing series of late night (and overnight) discussions highlighting the need to refine stereochemical nomenclature for coordination entities. Naturally, the nomenclature adopted in this review reflects the views of the authors and not an official IUPAC position or opinion. As always, we thank the Universities of Basel and Canterbury for their support.

Conflicts of Interest: The authors declare no conflict of interest. 


\section{References}

1. Constable, E.C.; Housecroft, C.E. The Early Years of 2,2'-Bipyridine-A Ligand in Its Own Lifetime. Molecules $2019,24,3951$. [CrossRef] [PubMed]

2. Brandt, W.W.; Dwyer, F.P.; Gyarfas, E.D. Chelate Complexes of 1,10-Phenanthroline and Related Compounds. Chem. Rev. 1954, 54, 959-1017. [CrossRef]

3. Lindoy, L.F.; Livingstone, S.E. Complexes of iron(II),cobalt(II) and nickel(II) with $\alpha$-diimines and related bidentate ligands. Coord. Chem. Rev. 1967, 2, 173-193. [CrossRef]

4. Accorsi, G.; Listorti, A.; Yoosaf, K.; Armaroli, N. 1,10-Phenanthrolines: Versatile building blocks for luminescent molecules, materials and metal complexes. Chem. Soc. Rev. 2009, 38, 1690. [CrossRef] [PubMed]

5. Bencini, A.; Lippolis, V. 1,10-Phenanthroline: A versatile building block for the construction of ligands for various purposes. Coord. Chem. Rev. 2010, 254, 2096-2180. [CrossRef]

6. McWhinnie, W.R.; Miller, J.D. The Chemistry of Complexes Containing 2,2'-Bipyridyl, 1, 10-Phenanthroline, or 2,2',6' $2^{\prime \prime}$ Terpyridyl as Ligands. In Advances in Inorganic Chemistry and Radiochemistry; Elsevier: Amsterdam, The Netherlands, 1970; pp. 135-215. ISBN 9780120236121.

7. Constable, E.C. Homoleptic Complexes of 2,2'-Bipyridine. In Advances in Inorganic Chemistry; Elsevier: Amsterdam, The Netherlands, 1989; pp. 1-63. ISBN 9780120236343.

8. Kaes, C.; Katz, A.; Hosseini, M.W. Bipyridine: The Most Widely Used Ligand. A Review of Molecules Comprising at Least Two 2,2'-Bipyridine Units. Chem. Rev. 2000, 100, 3553-3590. [CrossRef] [PubMed]

9. Summers, L.A. The Phenanthrolines. In Advances in Heterocyclic Chemistry: Advances in Heterocyclic Chemistry; Elsevier: Amsterdam, The Netherlands, 1978; Volume 22, pp. 1-69. ISBN 9780120206223.

10. Summers, L.A. The Bipyridines. In Advances in Heterocyclic Chemistry: Advances in Heterocyclic Chemistry; Elsevier: Amsterdam, The Netherlands, 1984; Volume 35, pp. 281-374. ISBN 9780120206353.

11. Groom, C.R.; Bruno, I.J.; Lightfoot, M.P.; Ward, S.C. The Cambridge Structural Database. Acta Crystallogr. 2016, 72B, 171-179. [CrossRef]

12. Bruno, I.J.; Cole, J.C.; Edgington, P.R.; Kessler, M.; Macrae, C.F.; McCabe, P.; Pearson, J.; Taylor, R. New software for searching the Cambridge Structural Database and visualizing crystal structures. Acta Crystallogr. 2002, 53, 226-235. [CrossRef] [PubMed]

13. Macrae, C.F.; Sovago, I.; Cottrell, S.J.; Galek, P.T.A.; McCabe, P.; Pidcock, E.; Platings, M.; Shields, G.P.; Stevens, J.S.; Towler, M.; et al. Mercury 4.0: From visualization to analysis, design and prediction. J. Appl. Crystallogr. 2020, 53, 226-235. [CrossRef] [PubMed]

14. Eliel, E.L.; Wilen, S.H.; Mander, L.N. Stereochemistry of Organic Compounds; John Wiley \& Sons: Hoboken, NJ, USA, 1994; ISBN 9780471016700.

15. Christie, G.H.; Kenner, J. LXXI.-The molecular configurations of polynuclear aromatic compounds. Part I. The resolution of $\gamma-6: 6^{\prime}$-dinitro- and 4:6:4' $: 6^{\prime}$-tetranitro-diphenic acids into optically active components. J. Chem. Soc. Trans. 1922, 121, 614-620. [CrossRef]

16. Cain, J.C.; Coulthard, A.; Micklethwait, F.M.G. CCXLII.-Studies in the diphenyl series. Part II. The dinitrobenzidines: A new form of isomerism. J. Chem. Soc. Trans. 1912, 101, 2298-2304. [CrossRef]

17. King, H. The possibility of a new instance of optical activity without an asymmetric carbon atom. Proc. Chem. Soc. 1914, 30, 250. [CrossRef]

18. Thorpe, J.F. John Cannell Cain. J. Chem. Soc. Trans. 1921, 119, 533-537.

19. Kuhn, R. Molekulare Asymmetrie. In Stereochemie: Eine zusammenfassung der Ergebnisse, Grundlagen und Probleme; Freudenberg, K., Ed.; Franz Deutike: Leipzig, Germany; Vienna, Austria, 1933; pp. 803-824.

20. Favre, H.A.; Powell, W.H. Nomenclature of Organic Chemistry: Iupac Recommendations and Preferred Names 2013; RSC Publishing: Cambridge, UK, 2014.

21. Cahn, R.S.; Ingold, C.K. Specification of configuration about quadricovalent asymmetric atoms. J. Chem. Soc. 1951, 612-622. [CrossRef]

22. Cahn, R.S.; Ingold, C.K.; Prelog, V. The specification of asymmetric configuration in organic chemistry. Experientia 1956, $12,81-94$. [CrossRef]

23. Cahn, R.S.; Ingold, C.; Prelog, V. Specification of Molecular Chirality. Angew. Chem. Int. Ed. Engl. 1966, 5, 385-415. [CrossRef]

24. Prelog, V.; Helmchen, G. Basic Principles of the CIP-System and Proposals for a Revision. Angew. Chem. Int. Ed. Engl. 1982, 21, 567-583. [CrossRef]

25. Ōki, M. Recent Advances in Atropisomerism.; Allinger, N.L., Eliel, E.L., Wilen, S.H., Eds.; John Wiley \& Sons, Inc.: Hoboken, NJ, USA, 1983; pp. 1-82. ISBN 0-471-89858.

26. Alkorta, I.; Elguero, J.; Roussel, C.; Vanthuyne, N.; Piras, P. Atropisomerism and Axial Chirality in Heteroaromatic Compounds. In Advances in Heterocyclic Chemistry; Katritzky, A.R., Ed.; Elsevier: Amsterdam, The Netherlands, 2012; Volume 105, pp. 1-188. ISBN 9780123965301.

27. Akutagawa, S. Asymmetric synthesis by metal BINAP catalysts. Appl. Catal. A 1995, 128, 171-207. [CrossRef]

28. Kitamura, M.; Noyori, R.; Tsukamoto, M. (R)- \& (S)-2,2'-Bis(diphenylphosphino)-1,1'-binaphthyl. e-EROS Encycl. Reag. Org. Synth. 2001. [CrossRef]

29. Kuriyama, W.; Sayo, N.; Saito, T. Chiral ligands \& their complexes. Newly available on a commercial scale. Strem Chem. 2007, 23, 1-73. 
30. Misra, A.; Dwivedi, J.; Kishore, D. Role of the transition metal complexes of 2,2'-bis(diphenylphosphino)-1,1'-binaphthyl (BINAP) in asymmetric catalysis. Synth. Commun. 2017, 47, 497-535. [CrossRef]

31. Noyori, R.; Takaya, H. BINAP: An efficient chiral element for asymmetric catalysis. Acc. Chem. Res. 1990, 23, 345-350. [CrossRef]

32. Noyori, R. Asymmetric catalysis by chiral metal complexes. CHEMTECH 1992, 22, 360-367.

33. Noyori, R. Asymmetric hydrogenation. Acta Chem. Scand. 1996, 50, 380-390. [CrossRef]

34. Ohkuma, T.; Kurono, N. BINAP. Privil. Chiral Ligands Catal. 2011, 1-53. [CrossRef]

35. Strong, J.G. BINAP—the people's ligand for chiral chemistry. PharmaChem 2003, 2, $20-22$.

36. Jones, M.D.; Almeida Paz, F.A.; Davies, J.E.; Johnson, B.F.G. (S)-(-)-2,2'-Bis(diphenylphosphino)-1,1'-binaphthyl, a versatile chelating ligand. Acta Crystallogr. Sect. E Struct. Rep. Online 2003, 59, o535-o537. [CrossRef]

37. Wu, X.; Huang, C.Y.; Chen, D.G.; Liu, D.; Wu, C.; Chou, K.J.; Zhang, B.; Wang, Y.; Liu, Y.; Li, E. Y.; et al. Exploiting racemism enhanced organic room-temperature phosphorescence to demonstrate Wallach's rule in the lighting chiral chromophores. Nat. Commun. 2020, 11, 2145. [CrossRef]

38. Deeming, A.J.; Speel, D.M.; Stchedroff, M. Trinuclear Clusters of Ruthenium-Containing Bridging and Ortho-Metalated 2,2'-Bis(diphenylphosphino)-1,1'-binaphthyl (BINAP): X-ray Structures of $(R)$-BINAP and $\left[\mathrm{Ru}_{3}(\mu-\mathrm{OH})_{2}(\mathrm{CO})_{8}\{\mu-(R)-\mathrm{BINAP}\}\right]$. Organometallics 1997, 16, 6004-6009. [CrossRef]

39. Niu, F.; Chai, W.; Song, L.; Zhou, M.; Liang, J. rac-2,2'-Bis(diphenyl-phosphan-yl)-1,1'-binaphth-yl: A racemic diphosphine ligand. Acta Crystallogr. Sect. E Struct. Rep. Online 2012, 68, o2033. [CrossRef]

40. Véron, A.C.; Felber, M.; Blacque, O.; Spingler, B. Conformational flexibility of palladium BINAP complexes explored by X-ray analyses and DFT studies. Polyhedron 2013, 52, 102-105. [CrossRef]

41. Crawford, M.; Smyth, I.F.B. The optical resolution and racemisation of some diisoquinolyls. J. Chem. Soc. 1954, 3464. [CrossRef]

42. Hirao, K.-I.; Tsuchiya, R.; Yano, Y.; Tsue, H. Preparation of optically active 8,8'-disubstituted 1,1'-biisoquinoline. Heterocycles 1996, 42, 415-422. [CrossRef]

43. Chelucci, G.; Cabras, M.A.; Saba, A.; Sechi, A. Synthesis and resolution of 1,1-bi-8-methylisoquinoline: Formation of an optically active complex with high chiral recognition. Tetrahedron Asymmetry 1996, 7, 1027-1032. [CrossRef]

44. Dai, L.; Zhou, Z.; Zhang, Y.; Ni, C.; Zhang, Z.; Zhou, Y. 1,1'-Biisoquinoline: A chiral bidentate N-donor ligand with C2-symmetry. Formation of optically active complexes with high chiral recognition. J. Chem. Soc., Chem. Commun. 1987, 1760-1762. [CrossRef]

45. Tsue, H.; Fujinami, H.; Itakura, T.; Tsuchiya, R.; Kobayashi, K.; Takahashi, H.; Hirao, K.-i. 8,8'-Dialkyl-1,1'-biisoquinolines: Preparation, absolute configuration and unexpected racemization behaviour. J. Chem. Soc. Perkin Trans. 1 1999, 3677-3683. [CrossRef]

46. Tsue, H.; Fujinami, H.; Itakura, T.; Tsuchiya, R.; Kobayashi, K.; Takahashi, H.; Hirao, K.-I. Absolute configuration of 8,8'-dialkyl1,1'-biisoquinoline. Chem. Lett. 1999, 17-18. [CrossRef]

47. Fujii, M.; Honda, A. Axially chiral heteroaromatics. 1. Preparation of optically active $1,1^{\prime}$-biisoquinoline $N, N^{\prime}$-dioxide. J. Heterocycl. Chem. 1992, 29, 931-933. [CrossRef]

48. Fujii, M.; Honda, A. Preparation of an axially chiral heteroaromatic compound 1,1'-biisoquinoline- $N, N^{\prime}$-dioxide. Chem. Express 1992, 7, 329-332.

49. Reep, C.; Morgante, P.; Peverati, R.; Takenaka, N. Axial-Chiral Biisoquinoline N,N'-Dioxides Bearing Polar Aromatic C-H Bonds as Catalysts in Sakurai-Hosomi-Denmark Allylation. Org. Lett. 2018, 20, 5757-5761. [CrossRef]

50. Rooks, B.J.; Haas, M.R.; Sepulveda, D.; Lu, T.; Wheeler, S.E. Prospects for the Computational Design of Bipyridine $N, N^{\prime}$-Dioxide Catalysts for Asymmetric Propargylation Reactions. ACS Catal. 2015, 5, 272-280. [CrossRef]

51. Ricci, G.; Ruzziconi, R.; Giorgio, E. Atropisomeric (R,R)-2,2'-Bi([2]paracyclo [2](5,8)quinolinophane) and $(R, R)-1,1^{\prime}-B i([2] p a r-$ acyclo[2](5,8)isoquinolinophane): Synthesis, Structural Analysis, and Chiroptical Properties. J. Org. Chem. 2005, 70, $1011-1018$. [CrossRef] [PubMed]

52. Leister, D.; Kao, J. Theoretical studies of rotational barriers in 1,1'-biisoquinoline, 2,2'-biquinoline and substituted styrenes, alkenyl-naphthalenes, and alkyl-binaphthyls. J. Mol. Struct. Theochem. 1988, 168, 105-118. [CrossRef]

53. Yamamoto, K.; Tateishi, H.; Watanabe, K.; Adachi, T.; Matsubara, H.; Ueda, T.; Yoshida, T. Novel optically active 7,7'-bridged-1,1'biisoquinolines and their chelation to rhodium(I) ion. J. Chem. Soc. Chem. Commun. 1995, 1637-1638. [CrossRef]

54. Dyker, G.; Stirner, W.; Henkel, G.; Schreiner, P.R. Deracemization of a macrocyclic 1,1'-biisoquinoline. Helv. Chim. Acta 2008, 91, 904-913. [CrossRef]

55. Badr, M.Z.A.; Aly, M.M.; Abdel-Rahman, A.E. Molecular rearrangements: Part X. Pyrolysis of aniline, o- and p-toluidines, mesitidine and $\alpha$-naphthylamine. Indian J. Chem. Sect. B 1977, 15B, 381-382.

56. Badr, M.Z.A.; El-Sherief, H.A.H. Molecular rearrangements. V. Pyrolysis of $\alpha$-naphthylmethyl phenyl ether. Indian J. Chem. 1974, 12, 1067-1070.

57. Badr, M.Z.A.; Aly, M.M.; Salem, S.S. Molecular rearrangements-XII. Tetrahedron 1977, 33, 3155-3157. [CrossRef]

58. Alvarez, M.; Joule, J.A. Product class 5: Isoquinolines. Sci. Synth. 2005, 15, 661-838.

59. Allan, K.M.; Hong, B.D.; Stoltz, B.M. Expedient synthesis of 3-hydroxyisoquinolines and 2-hydroxy-1,4-naphthoquinones via one-pot aryne acyl-alkylation/condensation. Org. Biomol. Chem. 2009, 7, 4960-4964. [CrossRef]

60. Banik, T.; Betkekar, V.V.; Kaliappan, K.P. An Unprecedented, Lewis Acid-Mediated, Metal-Free Iodoannulation Strategy to Aromatic Iodides. Chem.-Asian J. 2018, 13, 3676-3680. [CrossRef]

61. Henry, R.A.; Moore, D.W. Intramolecular cyclization of N-alkyl-3,3' 4 4,4'-tetrahydro-1,1'-biisoquinolinium salts. J. Org. Chem. 1972, 37, 2039-2040. [CrossRef] 
62. Henry, R.A.; Nielsen, A.T.; Moore, D.W. Reactions of epimeric 2,2'-diacetyl-1,1' 2 2,2'-tetrahydro-1, $1^{\prime}$-biisoquinolines. J. Org. Chem. 1972, 37, 3206-3209. [CrossRef]

63. Elliott, I.W., Jr.; McGriff, R.B. Bimolecular compounds from dissolving-metal reductions of N-heterocyclics. J. Org. Chem. 1957, 22, 514-516. [CrossRef]

64. Hayashi, E.; Makino, H.; Higashino, T. Reaction of 4-isoquinolinecarbonitrile and its 2-oxide with cyanide ions in dimethyl sulfoxide. Yakugaku Zasshi 1974, 94, 1041-1044. [CrossRef]

65. Matsuo, I.; Takahashi, T.; Ohki, S. Synthesis of isoquinoline derivatives. I. Synthesis of 1,1'-biisoquinoline derivatives. Yakugaku Zasshi 1963, 83, 518-522. [CrossRef] [PubMed]

66. Li, S.; Lv, H.; Xie, R.; Yu, Y.; Ye, X.; Kong, X. The C-H Activation/Bidirecting Group Strategy for Selective Direct Synthesis of Diverse 1,1'-Biisoquinolines. Org. Lett. 2020, 22, 4207-4212. [CrossRef]

67. Katritzky, A.R.; Barcock, R.A.; Siskin, M.; Olmstead, W.N. Aqueous High-Temperature Chemistry of Carbo- and Heterocycles. 23.Reactions of Pyridine Analogs and Benzopyrroles in Supercritical Water at $460{ }^{\circ}$ C. Energy Fuels 1994, 8, 990-1001. [CrossRef]

68. Si, C.; Myers, A.G. A Versatile Synthesis of Substituted Isoquinolines. Angew. Chem. Int. Ed. 2011, 50, 10409-10413. [CrossRef]

69. Guillou, S.; Janin, Y.L. Optimized palladium-based approaches to analogues of PK 11195. J. Heterocycl. Chem. 2008, 45, 1377-1384. [CrossRef]

70. Iyoda, M.; Otsuka, H.; Sato, K.; Nisato, N.; Oda, M. Homocoupling of aryl halides using nickel(II) complexes and zinc in the presence of tetraethylammonium iodide. An efficient method for the synthesis of biaryls and bipyridines. Bull. Chem. Soc. Jpn. 1990, 63, 80-87. [CrossRef]

71. Nelson, T.D.; Crouch, R.D. Cu, Ni, and Pd mediated homocoupling reactions in biaryl syntheses: The Ullmann reaction. Org. React. 2004, 63. [CrossRef]

72. Ashby, M.T.; Govindan, G.N.; Grafton, A.K. Metal-Assisted Racemization of the Atropisomers of a 1,1'-Binaphthyl Skeleton via a Syn Transition State. J. Am. Chem. Soc. 1994, 116, 4801-4809. [CrossRef]

73. Clarke, A.J.; McNamara, S.; Meth-Cohn, O. Novel aspects of the metalation of heterocycles. Side-chain metalation of thiophene and ring metalation of six-membered nitrogen heterocycles. Tetrahedron Lett. 1974, 2373-2376. [CrossRef]

74. Frediani, P.; Giannelli, C.; Salvini, A.; Ianelli, S. Ruthenium complexes with 1,1'-biisoquinoline as ligand. Synthesis and hydrogenation activity. J. Organomet. Chem. 2003, 667, 197-208. [CrossRef]

75. Banerji, A.; Maiti, S. Reactions of single-electron transfer reagents. Part II. Reaction of isoquinoline with sodium naphthalenide. Indian J. Chem. Sect. B 1993, 32B, 889-891.

76. Banerji, A.; Maiti, S. Studies on single-electron transfer reagents. Part IV. Reaction of nitrogen heterocycles with sodium naphthalenide. Tetrahedron 1994, 50, 9079-9096. [CrossRef]

77. Onggo, D.; Goodwin, H.A. Steric effects of the spin state of iron(II) in complexes of substituted bipyridine derivatives. Aust. J. Chem. 1991, 44, 1539-1551. [CrossRef]

78. Rapoport, H.; Iwamoto, R.; Tretter, J.R. The Synthesis of 2,2'-Biquinolyls and Related Compounds by Catalytic Dehydrogenation. J. Org. Chem. 1960, 25, 372-373. [CrossRef]

79. Wibaut, J.P.; Haaijman, P.W. On a remarkable formation of isocarbostyril from isoquinoline. Recueil des Travaux Chimiques des Pays-Bas 1943, 62, 466-468. [CrossRef]

80. Carey, J.C.; Sasse, W.H.F. Synthetic applications of activated metal catalysts. XXVI. Formation of biaryls from azahydrocarbons under the influence of rhodium-on-carbon. Aust. J. Chem. 1968, 21, 207-216. [CrossRef]

81. Case, F.H. The preparation of 1,1'- and 3,3'-biisoquinoline. J. Org. Chem. 1952, 17, 471-472. [CrossRef]

82. Falk, H.; Suste, A. On the chemistry of pyrrole pigments. XCI: Copper complexes of pyridinologous linear tri- and tetrapyrroles as cyclopropanation catalysts. Monatsh. Chem. 1994, 125, 325-333. [CrossRef]

83. Scherrer, D.; Schilling, M.; Luber, S.; Fox, T.; Spingler, B.; Alberto, R.; Richmond, C.J. Ruthenium water oxidation catalysts containing the non-planar tetradentate ligand, biisoquinoline dicarboxylic acid (biqaH ${ }_{2}$ ). Dalton Trans. 2016, 45, 19361-19367. [CrossRef]

84. Starke, I.; Kammer, S.; Holdt, H.-J.; Kleinpeter, E. Stability of disubstituted copper complexes in the gas phase analyzed by electrospray ionization mass spectrometry. Rapid Commun. Mass Spectrom. 2010, 24, 1319-1326. [CrossRef] [PubMed]

85. Starke, I.; Koch, A.; Kammer, S.; Holdt, H.-J.; Moeller, H.M. Electrospray mass spectrometry and molecular modeling study of formation and stability of silver complexes with diazaperylene and bisisoquinoline. J. Mass Spectrom. 2018, 53, 408-418. [CrossRef] [PubMed]

86. Kapatsina, E.; Lordon, M.; Baro, A.; Laschat, S. Convergent synthesis of 1,1'-biisoquinolines tethered to calamitic subunits. Synthesis 2008, 2551-2560. [CrossRef]

87. Kapatsina, E.; Mateescu, M.; Baro, A.; Frey, W.; Laschat, S. Concise Synthesis of [1,1'-Biisoquinoline]-4,4'-diol via a Protecting Group Strategy and Its Application for Potential Liquid-Crystalline Compounds. Helv. Chim. Acta 2009, 92, 2024-2037. [CrossRef]

88. Chang, Y.; Lee, S.; Cho, M.; Yoo, B.; Rhee, H.; Lee, S.; Yoon, C. Homocoupling of aryl iodides and bromides using a palladium/indium bimetallic system. Synth. Commun. 2005, 35, 1851-1857. [CrossRef]

89. Wang, Z.-J.; Wang, X.; Lv, J.-J.; Feng, J.-J.; Xu, X.; Wang, A.-J.; Liang, Z. Bimetallic Au-Pd nanochain networks: Facile synthesis and promising application in biaryl synthesis. New J. Chem. 2017, 41, 3894-3899. [CrossRef] 
90. Liu, Y.; Berges, J.; Zaid, Y.; Chahdi, F.O.; Van Der Lee, A.; Harakat, D.; Clot, E.; Jaroschik, F.; Taillefer, M. Aerobic and Ligand-Free Manganese-Catalyzed Homocoupling of Arenes or Aryl Halides via in Situ Formation of Aryllithiums. J. Org. Chem. 2019, 84, 4413-4420. [CrossRef]

91. Zhao, Q.; Liu, S.; Shi, M.; Wang, C.; Yu, M.; Li, L.; Li, F.; Yi, T.; Huang, C. Series of New Cationic Iridium(III) Complexes with Tunable Emission Wavelength and Excited State Properties: Structures, Theoretical Calculations, and Photophysical and Electrochemical Properties. Inorg. Chem. 2006, 45, 6152-6160. [CrossRef]

92. Duong, V.K.; Horan, A.M.; McGarrigle, E.M. Synthesis of Pyridylsulfonium Salts and Their Application in the Formation of Functionalized Bipyridines. Org. Lett. 2020, 22, 8451-8457. [CrossRef]

93. Duong, V.K.; Horan, A.M.; McGarrigle, E.M. Synthesis of pyridylsulfonium salts and their application in transition metal-free formation of functionalized bipyridines. ChemRxiv 2020, 1-5. [CrossRef]

94. Stephens, D.E.; Lakey-Beitia, J.; Burch, J.E.; Arman, H.D.; Larionov, O.V. Mechanistic insights into the potassium tert-butoxidemediated synthesis of N-heterobiaryls. Chem. Commun. 2016, 52, 9945-9948. [CrossRef]

95. Jha, A.K.; Jain, N. 2,2'-Homocoupled Azine N,N'-Dioxides or Azine N-Oxides: CDC- or SNAr-Controlled Chemoselectivity. Eur. J. Org. Chem. 2017, 2017, 4765-4772. [CrossRef]

96. Bulygina, L.A.; Khrushcheva, N.S.; Sokolov, V.I.; Khodak, A.A. Synthesis and catalytic activity of a complex of 1,1'-bis-isoquinoline $\mathrm{N}, \mathrm{N}^{\prime}$-dioxide with $\mathrm{PdCl}_{2}$. Russ. Chem. Bull. 2015, 64, 429-431. [CrossRef]

97. Malkov, A.V.; Westwater, M.-M.; Gutnov, A.; Ramirez-Lopez, P.; Friscourt, F.; Kadlcikova, A.; Hodacova, J.; Rankovic, Z.; Kotora, M.; Kocovsky, P. New pyridine $N$-oxides as chiral organocatalysts in the asymmetric allylation of aromatic aldehydes. Tetrahedron 2008, 64, 11335-11348. [CrossRef]

98. Nakajima, M.; Saito, M.; Shiro, M.; Hashimoto, S.-i. (S)-3,3'-Dimethyl-2,2'-biquinoline N,N'-Dioxide as an Efficient Catalyst for Enantioselective Addition of Allyltrichlorosilanes to Aldehydes. J. Am. Chem. Soc. 1998, 120, 6419-6420. [CrossRef]

99. Liu, B.; Feng, X.; Chen, F.; Zhang, G.; Cui, X.; Jiang, Y. Enantioselective Strecker reaction promoted by chiral N-oxides. Synlett 2001, 1551-1554. [CrossRef]

100. Denmark, S.E.; Fan, Y. Catalytic, Enantioselective Aldol Additions to Ketones. J. Am. Chem. Soc. 2002, 124, 4233-4235. [CrossRef]

101. Denmark, S.E.; Fan, Y.; Eastgate, M.D. Lewis Base Catalyzed, Enantioselective Aldol Addition of Methyl Trichlorosilyl Ketene Acetal to Ketones. J. Org. Chem. 2005, 70, 5235-5248. [CrossRef]

102. Nakajima, M.; Saito, M.; Uemura, M.; Hashimoto, S. Enantioselective ring opening of meso-epoxides with tetrachlorosilane catalyzed by chiral bipyridine $\mathrm{N}, \mathrm{N}^{\prime}$-dioxide derivatives. Tetrahedron Lett. 2002, 43, 8827-8829. [CrossRef]

103. Nakajima, M.; Yokota, T.; Saito, M.; Hashimoto, S. Enantioselective aldol reactions of trichlorosilyl enol ethers catalyzed by chiral $\mathrm{N}, \mathrm{N}^{\prime}$-dioxides and monodentate N-oxides. Tetrahedron Lett. 2004, 45, 61-64. [CrossRef]

104. Sugiura, M.; Sato, N.; Sonada, Y.; Kotani, S.; Nakajima, M. Diastereo- and enantioselective reductive aldol reaction with trichlorosilane using chiral Lewis bases as organocatalysts. Chem.-Asian J. 2010, 5, 478-481. [CrossRef] [PubMed]

105. Doney, A.C.; Rooks, B.J.; Lu, T.; Wheeler, S.E. Design of Organocatalysts for Asymmetric Propargylations through Computational Screening. ACS Catal. 2016, 6, 7948-7955. [CrossRef]

106. Jiao, Z.; Feng, X.; Liu, B.; Chen, F.; Zhang, G.; Jiang, Y. Enantioselective Strecker reactions between aldimines and trimethylsilyl cyanide promoted by chiral N,N'-dioxides. Eur. J. Org. Chem. 2003, 3818-3826. [CrossRef]

107. Nakanishi, K.; Kotani, S.; Sugiura, M.; Nakajima, M. First asymmetric Abramov-type phosphonylation of aldehydes with trialkyl phosphites catalyzed by chiral Lewis bases. Tetrahedron 2008, 64, 6415-6419. [CrossRef]

108. Grunwald, N.; Kelling, A.; Holdt, H.-J.; Schilde, U. The crystal structure of 1,1'-bisisoquinoline, $\mathrm{C}_{18} \mathrm{H}_{12} \mathrm{~N}_{2}$. Z. Kristallogr.-New Cryst. Struct. 2017, 232, 839-841. [CrossRef]

109. Mori, Y.; Matsuyama, Y.; Yamada, S.; Maeda, K. Structures of 2,2'-polymethylene-1,1'-biisoquinolinium dibromides. Acta Crystallogr. Sect. C Cryst. Struct. Commun. 1992, C48, 894-897. [CrossRef]

110. Mori, Y.; Matsuyama, Y.; Suzuki, J.; Ishii, Y.; Yamada, S.; Maeda, K. Structure of diiodide salts of N-heteroaromatic dications. Acta Crystallogr. Sect. C Cryst. Struct. Commun. 1993, C49, 1398-1401. [CrossRef]

111. Mori, Y.; Isozaki, K.; Maeda, K. Chemiluminescence of 1,1'-biisoquinolinium and 2,2'-biquinolinium salts. Reactions of electronrich olefins with molecular oxygen. J. Chem. Soc. Perkin Trans. 2 1997, 1969-1976. [CrossRef]

112. Maeda, K.; Matsuyama, Y.; Isozaki, K.; Yamada, S.; Mori, Y. Mechanism of the chemiluminescence of biisoquinolinium salts. J. Chem. Soc. Perkin Trans. 2 1996, 121-126. [CrossRef]

113. Mason, S.F.; Roberts, D.R. A new series of chemiluminescent reactions. Chem. Commun. 1967, 476-477. [CrossRef]

114. Yamamoto, K.; Watanabe, K.; Chikamatsu, H.; Okamoto, Y.; Yoshida, T. Preparation of a novel optically active 8,8'-biisoquinolyl and its coordination as a bridging ligand in rhodium(I) complexes. J. Chem. Soc. Chem. Commun. 1987, 807-809. [CrossRef]

115. Murali, M.; Palaniandavar, M. Synthesis, structure and spectral and redox properties of new mixed ligand monomeric and dimeric $\mathrm{Ru}(\mathrm{ii})$ complexes: Predominant formation of the "cis- $\alpha$ " diastereoisomer and unusual ${ }^{3} \mathrm{MC}$ emission by dimeric complexes. Dalton Trans. 2006, 730-743. [CrossRef] [PubMed]

116. D'Alessandro, D.M.; Keene, F.R. Metal-metal interactions in dinuclear ruthenium complexes incorporating "stepped-parallel" bridging ligands: Synthesis, stereochemistry and intervalence charge transfer. New J. Chem. 2006, 30, 228. [CrossRef]

117. Temizsoy, M.; Sethi, W.; Reinholdt, A.; Schau-Magnussen, M.; Bendix, J.; Hammershøi, A. Stereoretentive formylation of (S)proline: New application of the self-regeneration of stereo-centres (SRS) principle via chelation to cobalt(iii). Dalton Trans. 2015, 44, 18438-18446. [CrossRef] 
118. Dreos, R.; Nardin, G.; Randaccio, L.; Siega, P.; Tauzher, G. Synthesis, characterization, and solution behavior of optically active cis beta organocobalt salen complexes with L-amino acids. Inorg. Chem. 2004, 43, 3433-3440. [CrossRef] [PubMed]

119. Hua, X.; von Zelewsky, A. Enantiomerically Pure Chiral Ru $\mathrm{u}^{\mathrm{II}}(\mathrm{L}-\mathrm{L}) 2$ Building Blocks for Coordination Compounds. Inorg. Chem. 1995, 34, 5791-5797. [CrossRef]

120. Paul, P.; Tyagi, B.; Bilakhiya, A.K.; Dastidar, P.; Suresh, E. Metal-assisted unusual hydroxylation at the carbon atom of the triazine ring in dinuclear ruthenium(II) and osmium(II) complexes bridged by 2,4,6-tris(2-pyridyl)-1,3,5-triazine: Synthesis, structural characterization, stereochemistry, and electrochemical studies. Inorg. Chem. 2000, 39, 14-22. [CrossRef] [PubMed]

121. Prabaharan, R.; Fletcher, N.C. The stereoselective coordination chemistry of the helicating ligand N, $\mathrm{N}^{\prime}$-bis(-2,2' -dipyridyl-5yl)carbonyl-(S/R,S/R)-1,2-diphenylethylenediamine. Inorg. Chim. Acta 2003, 355, 449-453. [CrossRef]

122. Bergman, S.D.; Goldberg, I.; Barbieri, A.; Kol, M. Mononuclear and dinuclear complexes of isoeilatin. Inorg. Chem. 2005, 44, 2513-2523. [CrossRef] [PubMed]

123. Fernández-Cestau, J.; Giménez, N.; Lalinde, E.; Montaño, P.; Moreno, M.T.; Sánchez, S. Synthesis, Characterization, and Properties of Doubly Alkynyl Bridging Dinuclear Cyclometalated Iridium(III) Complexes. Organometallics 2015, 34, 1766-1778. [CrossRef]

124. Connelly, N.G. Iupac Recommendations 2005; Royal Society of Chemistry: London, UK, 2005; ISBN 9780854044382.

125. Grunwald, N.; Schilde, U.; Kelling, A.; Holdt, H.-J. De Gruyter. Available online: https://www.degruyter.com/document/doi/ 10.1515/ncrs-2017-0088/html (accessed on 1 March 2021).

126. Starke, I.; Kammer, S.; Grunwald, N.; Schilde, U.; Holdt, H.-J.; Kleinpeter, E. Complexation of diazaperylene and bisisoquinoline with transition metal ions in the gas phase studied by electrospray ionization mass spectrometry. Rapid Commun. Mass Spectrom. 2008, 22, 665-671. [CrossRef] [PubMed]

127. Shen, H.; Zhou, X.; Zhou, S.; Mao, H. Synthesis, characterization of homogeneous Fe-catalyst and its application in selective oxidation of alcohols to aldehydes and ketones. Chem. J. Internet 2005, 7, 56.

128. Ashby, M.T.; Govindan, G.N.; Grafton, A.K. Kinetics and mechanism of the facile diastereomeric isomerization of a tris(bidentate)ruthenium(II) complex bearing a misdirected bipyridyl ligand: $\Delta \Lambda-\left(\delta / \lambda-1,1^{\prime}\right.$-biisoquinoline)bis(2,2'bipyridine)ruthenium(II). Inorg. Chem. 1993, 32, 3803-3804. [CrossRef]

129. Marsh, R.E.; Clemente, D.A. A survey of crystal structures published in the Journal of the American Chemical Society. Inorg. Chim. Acta 2007, 360, 4017-4024. [CrossRef]

130. Baranoff, E.; Collin, J.-P.; Furusho, J.; Furusho, Y.; Laemmel, A.-C.; Sauvage, J.-P. Photochemical or Thermal Chelate Exchange in the Ruthenium Coordination Sphere of Complexes of the Ru(phen $)_{2} \mathrm{~L}$ Family ( $\mathrm{L}=$ Diimine or Dinitrile Ligands). Inorg. Chem. 2002, 41, 1215-1222. [CrossRef] [PubMed]

131. Ashby, M.T. Inverse Relationship between the Kinetic and Thermodynamic Stabilities of the Misdirected Ligand Complexes $\Delta / \Lambda$ - $\left(\delta / \lambda-1,1^{\prime}\right.$-Biisoquinoline)bis(2,2'-bipyridine)metal(II) (metal = Ruthenium, Osmium). J. Am. Chem. Soc. 1995, 117, 2000-2007. [CrossRef]

132. Ashby, M.T.; Alguindigue, S.S.; Khan, M.A. Kinetic Element Effect for Atropisomerization of an Organometallic Complex of the Misdirected Ligand 1,1'-Biisoquinoline. Organometallics 2000, 19, 547-552. [CrossRef]

133. Ashby, M.T.; Alguindigue, S.S.; Schwane, J.D.; Daniel, T.A. Regular and Inverse Secondary Kinetic Enthalpy Effects (KHE) for the Rate of Inversion of Thioether and 1,1'-Biisoquinoline Complexes of Ruthenium and Osmium. Inorg. Chem. 2001, 40, 6643-6650. [CrossRef]

134. Brandt, P.; Norrby, T.; Aakermark, B.; Norrby, P.-O. Molecular mechanics (MM3) parameters for ruthenium(II)-polypyridyl complexes. Inorg. Chem. 1998, 37, 4120-4127. [CrossRef]

135. Yang, R.; Dai, L. Synthesis and electronic spectra of ruthenium(II)-1,1'-biisoquinoline complexes. Chin. Chem. Lett. 1993, 4, 1021-1024.

136. Zhu, Z.; Mao, C.; Yang, R.; Dai, L.; Nie, C. Surface-enhanced Raman scattering of ruthenium(II) homo- and heterolytic complexes with 2,2'-bipyridine and 1,1'-biisoquinoline in aqueous silver sol. J. Raman Spectrosc. 1993, 24, 221-226. [CrossRef]

137. Glazer, E.C.; Tor, Y. Ru ${ }^{\mathrm{II}}$ complexes of "large-surface" ligands. Angew. Chem. Int. Ed. 2002, 41, 4022-4026. [CrossRef]

138. Yu, W.-Y.; Cheng, W.-C.; Che, C.-M.; Wang, Y. Synthesis, redox properties and reactivities of ruthenium(II) complexes of 1,1'biisoquinoline $(\mathrm{BIQN})$ and $x$-ray crystal structure of $\left[\mathrm{Ru}^{\mathrm{II}}(\right.$ terpy) $(\mathrm{BIQN})(\mathrm{Cl})] \mathrm{ClO}_{4}\left(\right.$ terpy $=2,2^{\prime}: 6^{\prime}, 2^{\prime \prime}$-terpyridine). Polyhedron 1994, 13, 2963-2969. [CrossRef]

139. Yu, W.-Y.; Fung, W.-H.; Zhu, J.-L.; Cheung, K.-K.; Ho, K.-K.; Che, C.-M. Chiral ruthenium-oxo complexes for enantioselective epoxidation of trans-stilbene. J. Chin. Chem. Soc. (Taipei) 1999, 46, 341-349. [CrossRef]

140. Panda, S.; Goel, P.; Lahiri, G.K. Non-Spectator Feature of $\alpha$-Diimine Mimicked Di/tetrahydro-bisisoquinoline and Biimidazopyridine on $\left\{\mathrm{Ru}(\mathrm{acac})_{2}\right\}$ Platform. Eur. J. Inorg. Chem. 2020, 2020, 2004-2013. [CrossRef]

141. Tseng, H.-W.; Zong, R.; Muckerman, J.T.; Thummel, R. Mononuclear Ruthenium(II) Complexes That Catalyze Water Oxidation. Inorg. Chem. 2008, 47, 11763-11773. [CrossRef]

142. Liu, R.; Dandu, N.; Chen, J.; Li, Y.; Li, Z.; Liu, S.; Wang, C.; Kilina, S.; Kohler, B.; Sun, W. Influence of Different Diimine (NN) Ligands on the Photophysics and Reverse Saturable Absorption of Heteroleptic Cationic Iridium(III) Complexes Bearing Cyclometalating 2-\{3-[7-(Benzothiazol-2-yl)fluoren-2-yl]phenyl\}pyridine (CN) Ligands. J. Phys. Chem. C 2014, 118, 23233-23246. [CrossRef]

143. Khrushcheva, N.S.; Bulygina, L.A.; Starikova, Z.A.; Sokolov, V.I. Synthesis, structure, and catalytic activity of complexes of 1,1'-bisisoquinoline with $\mathrm{PdCl}_{2}$ and $\mathrm{NiCl}_{2}$. Russ. Chem. Bull. 2014, 63, 883-889. [CrossRef] 
144. Svensson, F.; Mane, R.S.; Saevmarker, J.; Larhed, M.; Skoeld, C. Theoretical and experimental investigation of palladium(II)catalyzed decarboxylative addition of arenecarboxylic acid to nitrile. Organometallics 2013, 32, 490-497. [CrossRef]

145. Cheng, L.K.; Yeung, K.S.; Che, C.M.; Cheng, M.C.; Wang, Y. X-ray structure and spectroscopic properties of platinum(II) complexes of 1,1'-biisoquinoline. Polyhedron 1993, 12, 1201-1207. [CrossRef]

146. Jahng, Y.; Park, J.G.; Yu, J.W. Synthesis and properties of $\mathrm{Cu}(\mathrm{I})$ complexes of isoquinoline-related bidentates. Bull. Korean Chem. Soc. 2000, 21, 333-335.

147. Arnosti, N.; Meyer, M.; Prescimone, A.; Constable, E.C.; Housecroft, C.E. Heteroleptic $\left[\mathrm{Cu}\left(\mathrm{P}^{\wedge} \mathrm{P}\right)\left(\mathrm{N}^{\wedge} \mathrm{N}\right)\right]\left[\mathrm{PF}_{6}\right]$ complexes: Effects of isomer switching from 2,2'-biquinoline to 1,1'-biisoquinoline. Crystals 2021, 11, 185. [CrossRef]

148. Bardaji, M.; Miguel-Coello, A.B.; Espinet, P. Predominance of bridging coordination in luminescent 1,1'-biisoquinoline silver(I) derivatives. Inorg. Chim. Acta 2012, 386, 93-101. [CrossRef]

149. Bardaji, M.; Miguel-Coello, A.B.; Espinet, P. Mono- and dinuclear luminescent 1,1'-biisoquinoline gold(I) complexes. Inorg. Chim. Acta 2012, 392, 91-98. [CrossRef] 